\title{
ARQUITETURA DA REDE FIBROVASCULAR DO CAULE DA CANA-DE-AÇÚCAR ( acoharum SPP.)
}

\author{
ROBERTO ANTONIO ARÉVALO
}

Orientador: PAULO NOGUEIRA DE CAMARGO

Tese apresentada à Escola Superior de Agricultura "Luiz de Queiroz", da Universidade de São Paulo, para obtenção do título de Doutor em Agronomia. Área de Concentração: Solos $\theta$ Nutrição de Plantas.

$P|R A C| C A B A$

Estado de São Paulo - Brasil

1984 
ii.

\section{DEDICATORIA}

A UNIUN CANEROS INDEPENOIENTE DE'TU CUMAN (UCIT) que durante os cinco anos de minha formação secundāria, custeou os meus estudos de Técnico Agrônomo, tendo assim despertado o meu amor à Ciência, e o meu interesse pela cana-de-açücar.

DEDICO. 


\section{iii.}

\section{AGRADECIMENTOS}

o autor manifesta seus mais profundos agradeci mentos às seguintes pessoas e instituições:

- Prof. Dr. PAULO NOGUEIRA DE CAMARGo, por sua dedicada e excelente orientação científica, na realização des te trabalho;

- Prof. Dr. HUMBERTO DE CAMPOS, pelo seu assesso ramento nos trabalhos estatisticos;

- Prof. Dr. RICARDO VICTÓRIA FILHO, pelas suas oportunas sugestões e por facilitar o uso dos laboratórios e dependências da Secção de Horticultura da ESALQ;

- Prof. Dr. ROBERTO ANTONIO ZUCCHI, por facilitar o uso do laboratório de microscopia do Departamento de Entomologia da ESALQ;

- Prof. Dr. OSWALDO PEREIRA DE GODOY, por ter facilitado o uso dos campos experimentais do Departamento de Agricultura da ESALQ, na realização das pesquisas de campo, deste trabalho;

- Prof. Dr. CLOVIS FERRAZ DE OLIVEIRA SANTOS, por ter facilitado o uso do laboratório de Microscopia do Departamento de Botânica - ESALQ.

- Prof. Dr. HIROSHI KIMATI, por ter facilitado o uso das dependências e laboratórios do Departamento de Fitopa tologia - ESALQ: 
- Profa. Dra. ROSA MARIA VALDEBEnito SANHUEZA, do Departamento de Fitopatologia -- ESALQ, pelas suas valiosas su gestões;

- Profa. Dra. GRACI MIRIAN CORSO, da Faculdade de Ciências e Letras de Rio Claro - UNESP, por ter facilitado o uso do laboratório de Botânica;

- Profa. MARILIA RODRIGUES PEREIRA DE NORONHA, do Departamento de Biologia Aplicada à Agropecuária, Campus de Ilha Solteira - UNESP, pela sua assessoria no uso de aparelhos de laboratório na Faculdade de Filosofia, Ciências e Letras de Rio Claro;

- Sr. PEDRO DA SILVA, auxiliar do laboratório de Fitopatologia da ESALQ por sua presteza e soiicitude, demonstradas no decorrer das pesquisas;

- Minha filha LILIANA DEL VALLE AREVALC CORDERO, pelo seu dedicado trabalho dos desenhos ilustrativos da tese;

- Engenheiros iLDO CORDERO EDUARDO e MIGUEL CORDE RO EDUARDO, pelo seu afetuoso estímulo, no decorrer das minhas pesquisas;

- Distintos colegas JOSE RAFAEL MENDEZ BALDEÓN, NORMAN A.S. COIO E MÁRTO MOLINA, pelo constante e entusiástico es timulo, no decorrer deste trabalho;

- Colegas HARRY LORENZI, M.S. da COPERSUCAR, e HERNĀN HOFFMANN, do PLANALSUCAR, por facilitár a obtençãode cana-semente, para este trabalho. 
- Fundação de amparo A pesquisa do estado de são PAULO - FAPESP, pela bolsa concedida, que permitiu a realiza ção deste trabalho;

- FEALQ - Fundação de Estudos AgRÁRIos luiz DE QUEIROZ", pelo auxílio financeiro para a edição desta tese;

- Euncionários da BIBLIOTECA CENTRAL DA ESALQ, que facilitaram por todos os meios, as informações utilizadas nesta tese;

- BIBLIOTECA DO CENA - CENTRO DE ENERgIA NUCLEAR NA AGRICULTURA, pela cooperação dos seus funcionários na obtenção de dados bibliográficos para esta tese.

O autor agradece também a todos os que direta ou indiretamente contribuiram para a realização deste trabalho. 
$\underline{\underline{I}} \underline{\mathrm{D}} \underline{\underline{I}} \underline{\mathrm{C}} \underline{\mathrm{E}}$

Página

DEDICATORIA $\ldots \ldots \ldots \ldots \ldots \ldots \ldots \ldots \ldots \ldots \ldots \ldots \ldots \ldots \ldots \ldots \ldots$

AGRADECIMENTOS $\ldots \ldots \ldots \ldots \ldots \ldots \ldots \ldots \ldots \ldots$

LISTA DE TABELAS $\ldots \ldots \ldots \ldots \ldots \ldots \ldots \ldots \ldots \ldots \ldots \ldots \ldots \ldots \ldots \ldots$ ix

LISTA DE FIGURAS $\ldots \ldots \ldots \ldots \ldots \ldots \ldots \ldots \ldots \ldots \ldots \ldots \ldots$

RESUMO $\ldots \ldots \ldots \ldots \ldots \ldots \ldots \ldots \ldots \ldots \ldots \ldots \ldots \ldots \ldots \ldots \ldots \ldots$ xiii

SUMMARY $\ldots \ldots \ldots \ldots \ldots \ldots \ldots \ldots \ldots \ldots \ldots \ldots \ldots \ldots \ldots \ldots \ldots \ldots \ldots$ xviii

1. INTRODUÇÃO $\ldots \ldots \ldots \ldots \ldots \ldots \ldots \ldots \ldots \ldots \ldots \ldots \ldots$

2. REVISÃO DA LITERATURA $\ldots \ldots \ldots \ldots \ldots \ldots \ldots \ldots \ldots$

3. MATERIAIS E METOdOS $\ldots \ldots \ldots \ldots \ldots \ldots \ldots \ldots \ldots \ldots$

3.1. Pesquisa I - Determinar a origem dos feixes fibrovasculares no tolete, sua passagem para o rizoma, e sua disposição arquitetôni ca no rizoma e no colmo ................

3.2. Pesquisa II - Determinar o curso descendente dos feixes centrais que emitem traços fo liares terminais e laterais através do colmo e suas possiveis conexões em seu trajeto

3.3. Pesquisa III - Determinar a posição do nó em que $\bigcirc$ plexo nodal (PN) já è funcio nal, em um cultivar precoce (NA 56-79) e em

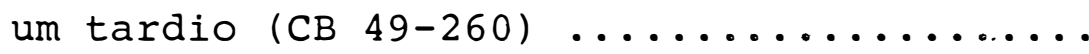

3.4. Pesquisa IV - Determinar, pela germinação, o nó mais jovem cujo plexo nodal (PN) já seja funcional, em um cultivar precoce (NA 5679) e em um tardio ( $\mathrm{CB}$ 49-260) . ........... 
vii.

Pāgina

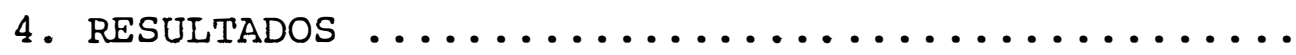

4.1. Pesquisa I - Determinar a origem dos feixes fibrovasculares no tolete, sua passagem para o rizoma, e sua disposição arquitetôni ca no rizoma e no colmo ...............

4.1.1. Origem dos sistemas fibrovasculares em NA $56-79 \ldots \ldots \ldots \ldots \ldots \ldots \ldots \ldots$

4.1.2. Origem dos sistemas fibrovasculares em CB $41-76 \ldots \ldots \ldots \ldots \ldots \ldots \ldots$

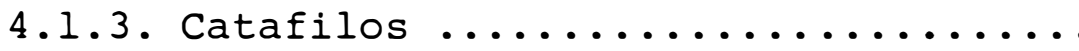

4.2. Pesquisa II - Determinar o curso descendente dos feixes centrais que emitem traços fo liares terminais e laterais através do colmo e suas possíveis conexões em seu traje-

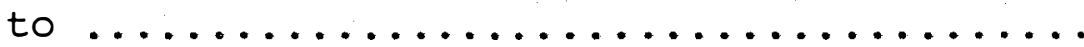

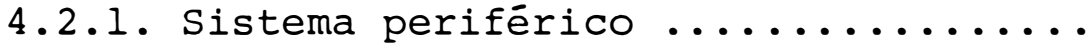

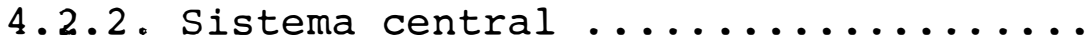

4.2.3. Curso descentente dos feixes centrais que emitem traços foliares ter minais e suas conexões ............

4.2.4. Traços foliares terminais do cV. NA

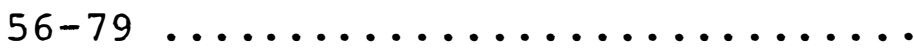

4.2.5. Traços foliares terminais do $\mathrm{CV} \cdot \mathrm{CB}$ $41-76 \ldots \ldots \ldots \ldots \ldots \ldots \ldots \ldots \ldots \ldots \ldots \ldots \ldots \ldots$

4.2.6. Traços foliares laterais ........

4.3. Pesquisa III - Determinar a posição do nó em que o plexo nodal (PN) já é funcional, em um cultivar precoce (NA 56-79) e em

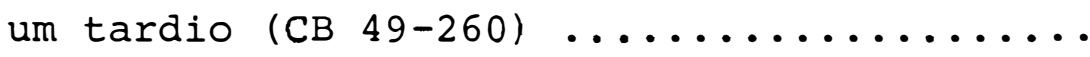


viii.

Pāgina

4.3.1. Cv. CB 49-260 - Região do nó +1 ....

4.3.2. cv. NA 56-79 - Região do nó +1 ....

4.3.3. CV. CB 49-260 - Região do nó +2 ...

4.3.4. cV. NA 56-79 - Região do nó +2 ....

4.3.5. Cv. CB 49-260 - Região do nó +3 ...

4.3.6. cv. NA 56-79 - Região do nó +3 ....

4.3.7. Cv. CB 49-260 - Região do nó +4 ...

4.3.8. cv. NA 56-79 - Região do nó +4 ...

4.3.9. cv. CB 49-260 - Região do nó +5 ...

4.3.10. Cv. NA 56-79 - Região do nō +5 ....

4.4. Pesquisa IV - Determinar, pela germinação, o nó mais jovem cujo plexo nodal (PN) já seja funcional, em um cultivar precoce (NA 56-79)

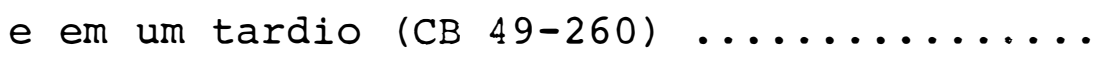

5. DISCUSSAีO .......................... 60

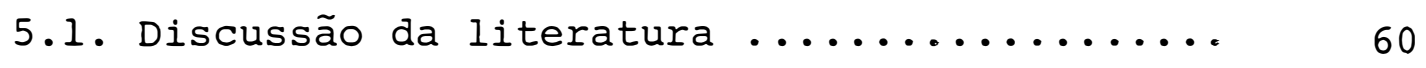

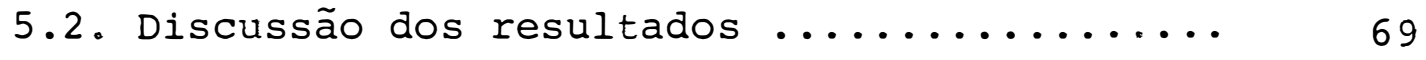

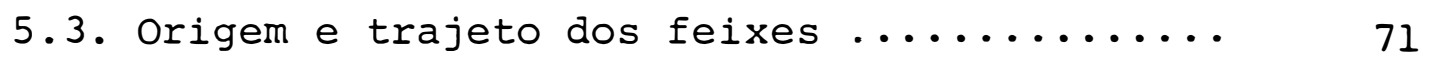

5.4. Considerações metodológicas ............. 72

6. CONCLUSÕES ........................... 74

6.1. Organização da rede fibrovascular ........ 74

6.2. Ramificações dos cordões do sp. ........... 75

6.3. Trajetória dos feixes de traços foliares cen

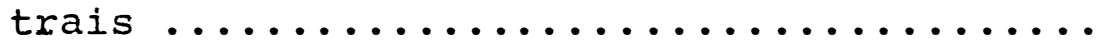

6.4. Ramificações e conexões dos feixes centrais 6.5. Diferenças varietais ................

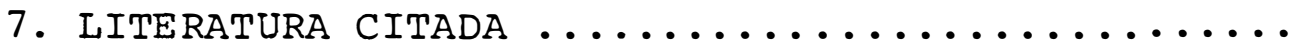


Plântulas emergidas 30 dias após o plantio. Cv. NA 56-79 ..........

Piântulas emergidas 30 dias após o plantio. Cv. CB 49-260 .......... 


\section{IISTA DE FIGURAS}

FIGURA NO

Pāgina

1 .

Esquema de uma sequência degomos em um trecho de colmo ...............

Esquema de uma touceira em formação.

Origem dos sistemas fibrovasculares,

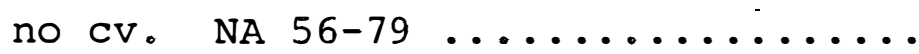

Aspecto geral da organização arquite tônica dos sistemas fibrovasculares, dos rizomas primário e secundário do cv. NA $56-79 \ldots \ldots \ldots \ldots \ldots \ldots$

Origem do sistema fibrovascular no cV. CB $41-76 \ldots \ldots \ldots \ldots \ldots \ldots$

Aspecto geral da organização arquite tônica dos sistemas fibrovasculares dos rizomas primário e secundário do cV. CB $41-76 \ldots \ldots \ldots \ldots \ldots \ldots$

Esquema de um rizoma, mostrando a evolução dos catafilos ...........

Vista geral de um trecho de colmo do cV. NA 56-79 celulolisado, mostrando - aspecto arquitetônico dos sistemas fibrovasculares, abrangendo 15 nōs $(+5 a+19) \quad \ldots \ldots \ldots \ldots \ldots \ldots \ldots \ldots$ 
Vista geral de um trecho de colmo do cV. CB 41-76, celulolisado, mostrando $\circ$ aspecto arquitetônico dos siste mas fibrovasculares, abrangendo 16 nōs $(n \bar{o}+5 a+20) \quad \ldots \ldots \ldots \ldots \ldots \ldots$

Aspectos da região do nó +1 , do $\mathrm{cV}$. CB $49-260 \ldots \ldots \ldots \ldots \ldots \ldots \ldots$

11 Aspecto da região do nó +1 , do cv. $\mathrm{NA} 56-79 \ldots \ldots \ldots \ldots \ldots \ldots \ldots \ldots$

Aspecto da região do nó +2 , do $\mathrm{cV}$. св $49-260 \ldots \ldots \ldots \ldots \ldots \ldots . \ldots \ldots$

Aspecto da região do nó +2 , do cV.

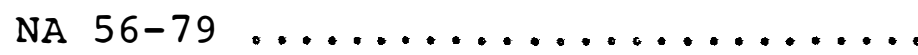

Aspecto da região do nó +3 , do $\mathrm{cv}$. $49-260 \ldots \ldots \ldots \ldots \ldots \ldots \ldots \ldots \ldots$

Aspecto da região do nó +3, do cv . NA $56-79 \ldots \ldots \ldots \ldots \ldots \ldots \ldots \ldots$

Aspecto da região do nó +4 , do cv. CB $49-260 \ldots \ldots \ldots \ldots \ldots \ldots \ldots \ldots$

Aspecto da região do nó +4 , do cV. NA 56-79

Aspecto da região do nó +5 , do $\mathrm{CV}$. CB $49-260 \ldots \ldots \ldots \ldots \ldots \ldots \ldots \ldots$ 
xii.

FIGURA NO

Pāgina

19

Aspecto da região do nó +5 , do $c v$.

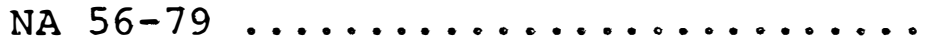

20

Diagrama mostrando o aspecto dual do sistema vascular, e o curso longitudinal de traços foliares em um caule vegetativo com 10 nós (Kumazawa, 1949b, cf. KUMAZAWA, 1961) ........

21

Estágios de amadurecimento dos feixes fibrovasculares, na área do me-

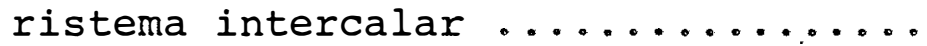


xiii.

ARQUITETURA DA REDE FIBROVASCULAR DO CAULE DA CANA-DE-AÇUCAR (Saccharum spp.)

Autor: ROBERTO ANTONIO AREVALO

Orientador: Prof. Dr. PAULO NOGUEIRA DE CAMARGO

RESUMO

Este trabalho foi realizado na Escola Superior de Agricultura "Luiz de Queiroz", Universidade de são Paulo, Brasil, em 1983-84. Seus objetivos foram o de elucidar "a arquitetura da rede fibrovascular do tolete, rizoma e colmo da cana-de-açúcar (Saccharum spp.) e determinar, em um cultivar precoce (NA 56-79) e em um tardio (CB 49-260), a posição do nó em que o plexo nodal já è funcional.

Foram realizadas as 4 seguintes pesquisas: I-De terminar a origem dos feixes fibrovasculares no tolete, sua passagem para o rizoma e sua disposição arquitetônica no rizo ma e no colmo; II - Determinar o curso descendente dos feixes centrais que emitem traços foliares terminais e laterais atravēs do colmo, e suas possíveis conexões, em seu trajeto; III - Determinar a posição do nó em que o plexo nodal já é funcional, em um cultivar precoce (NA 56-79) e em um tardio (CB 49-260); IV - Determinar, pela germinação, o nó mais jovem cujo plexo nodal já seja funcional, em um cultivar precoce (NA 56-79) e em um tardio (CB 49-260). 
xiv.

Para as pesquisas I e II, foram plantados 26 toletes unigemares de cada um dos cultivares NA 56-79 e $\mathrm{CB}$ 41-76, em caixas de $1 \mathrm{~m} 3$ de capacidade, com solo preparado $(1 / 3$ areia $+1 / 3$ solo argiloso $+1 / 3$ serapilheira). Na pesquisa I, as plantas originadas desses toletes foram cultivadas durante 4 meses. Nos 3 primeiros meses, receberam irrigação diária e, durante o 4 ㅇ mês, somente eram irrigadas quando apresentavam início de mur chamento (estresse hídrico), o que ocorria aproximadamente em intervalos de 1 semana. Este processo, conhecido como "envelhecimento precoce", produz internódios curtos e amadurecimen to precoce do meristema intercalar e de toda a rede fibrovascular. Na pesquisa II, as plantas foram cultivadas em estres se hídrico durante 18 meses, tendo produzido planas anãs. Foram cortados 25 colmos de cada pesquisa, partidos longitudinal mente, fervidos em água durante 10 minutos, para evitar crescimento durante a celulolisação e, depois de esfriados ao ambiente, colocados em caixas retangulares de ferro pintado com tinta anti-ferrugem, onde foram postos a celulolisar por microrganismos celulolíticos, segundo o método de AREvalo (1983). o método do envelhecimento precoce abreviou em 50\% o tempo da celulolisação. Após a celulolisação, o material foi cuida dosamente lavado em água de torneira, embrulhado em papel jor nal, etiquetado e conservado em congelador, para exames poste riores.

Para a pesquisa III, foram tomados, de cada cul 
tivar, 5 grupos de toletes uninodais, do nō +1 ao nó +5 Kuij per, partidos longitudinalmente, ao nível da gema, e postos a celulolisar em caixas plāsticas de $20 \times 20 \times 5 \mathrm{~cm}$, à temperatú ra ambiente ( $(229 \mathrm{C})$. Após a celulolisação, o material foi la vado, nas mesmas caixas, com ăgua de torneira, pipetada, e con servado nas mesmas caixas, no congelador.

Para a pesquisa IV, foi montado um experimento em blocos inteiramente casualizados, tomando-se 8 colmos de 5 meses de idade, de cada cultivar, os quais foram, respec tivamente, divididos em 10 toletes de 1 gema, a partir do tolete zero até o tolete +9-kuijper, e colocados para germinar em caixas com solo preparado como para as pesquisas I e II.

A origem e o trajeto dos fieixes fibrovascula res foram determinados no tolete, rizoma e colmo de cada cul tivar celulolisado, por meio de exames ao microscópio estereoscópico WILD M3, e desenhados em câmara clara. Duas rotas para os exames foram usados nesta pesquisa: a) partindo de um traço foliar, acompanhar o feixe respectivo, em seu trajeto descendente, até a sua origem; b) partindo de traços gemares, no tolete, acompanhar o trajeto ascendente do feixe, atra vés do rizoma e do colmo, até o traço foliar.

Essas duas pesquisas conduziram aos, seguintes resultados: a) o sistema fibrovascular periférico do caule (rí zoma e colmol origina-se do sistema fibrovascular do tolete; b) o sistema fibrovascular central do caule (rizoma e colmo) 
xvi.

origina-se de ambos os sistemas fibrovasculares - periférico e central - do tolete; c) os feixes centrais do caule podem também se originar no sistema fibrovascular periférico do rizoma ou do colmo.

As pesquisas III e IV revelaram que a funciona Iidade do plexo nodal depende da direção do gradiente de amadurecimento dos feixes axótropos. A pesquisa III mostrou que no meristema intercalar, o gradiente de amadurecimento dos feixes axōtropos é centrípetó no CV. CB 49-260, e centrífugo no cV. NA 56-79. Esta diferença varietal influencia a precocidade da germinação, pois a capacidade de germinação da gema depende essencialmente da presença de traços gemares maduros, e, no amadurecimento centrípeto dos feixes axótropos, os primeiros traços gemares a amadurecerem são os que estão mais pró ximos da gema.

A pesquisa IV mostrou que a mais jovem gema germinante era a do nó +2 , no cv. CB 49-260, embora, aparente mente, o amadurecimento centrípeto de seu plexo nodal tivesse se completado somente no nó +5 ; e no cv. NA 56-79, a mais jovem gema germinante era a do nó +3 , embora o amadurecimen to centrífugo de seu plexo nodal estivesse aparentemente completo no nó +2. Este fato parece indicar que, apesar de estar completo em sua disposição arquitetônica no nó +2, o plexo nodal deste cultivar ainda não tem traços gemares maduros neste nó.

Outra diferença varietal è que a . arquitetu- 
xvii.

ra fibrovascular dos catafilos é típica para cada um dos cultivares estudados, constituindo um caräter de diferenciação taxonômica. 
xviii.

ARCHITECTURE OF THE FIBROVASCULPR NET OF SUGARCANE

(Saccharum spp.) STEM.

Author: ROBERTO ANTONIO AREVALO

Adviser: Prof. Dr. PAULO NOGUEIRA DE CAMARGO

\section{SUMMARY}

These researches were carried out in the Escola Superior de Agricultura "Luiz de Queiroz", University of São Paulo, Brazil, during the period of 1983-84, with the following objectives: (a) to elucidate the architecture of the fibrovascular net of the sugarcane stem (rhizome and culm); and (b) to determine the first node in which the nodal plexus is already functional on a early season cultivar ( $\mathrm{Na} \mathrm{56-79),}$ and on a late season one (CB 49-260).

For achieving these two objectives, the following researches were carried out: I - To determine the origin of the fibrovascular bundles in the seed piece, their passage into the rhizome and their architectural arrangement along the rhizome and the culm; II - To determine the descendent course of the central bundles which produce terminal and lateral foliar traces along the culm, and their possible connections through their course; III - To determine the location of the node on which the nodal plexus is already 
xix.

functional, on a early season cultivar (NA 56-79) and on a late season one (CB 49-260); IV - To determine, by bud germination the youngest node whose nodal plexus is already functional, on the cultivars referred in IV.

For the researches I and II, 26 single bud seed pieces of each cultivar were planted in $1 \mathrm{~m}^{3}$ boxes with prepared soil ( $1 / 3$ sand $+1 / 3$ clay soil $+1 / 3$ wood organic soil). In the research I, the plants developed from the seed pieces were cultivated during four months. During the first three months, they were watered daily only when showing a beginning of wilt, which characterized a state of water stress which occurred at intervals of more or less one week. This process, known as "precocious aging", induces the formation of short internodes and of precocious ripening of the intercalar meristem, and of all the fibrovascular net. In the research II, the plants originated of the seed pieces were cultivated under water stress during 18 months, producing dwarf stems.

From each research, 25 stems were cut longitudinally, boiled in water during 10 minutes, for preventing growth during cellulolisation, and set into rectangular iron boxes painted with antioxidant ink, for cellulolising by microorganisms, according the method of AREVALO (1983). The process of precocious aging decreased by $50 \%$ the time of cellulolisation. After cellulolisation, the material was carefully washed in tap water, wrapped in newspaper sheets, 
labelled, and kept in a freezer, for further examination. For the research III, five groups of single bud seed pieces, from the +1 to the +5-kuijper node, were longitudinally cut at the level of the bud, and set into $20 \times 20 \times 5 \mathrm{~cm}$ plastic boxes, for cellulolising, at ambient temperature ( $\pm 228 \mathrm{C})$. After cellulolisation, the material was carefully washed by pipeting tap water, and conserved in the same boxes, kept in a freezer.

For the research IV, eight culms 5 months old of each cultivar were taken. Each culm was divided into 10 seed pieces of one bud, including the ones from number zero to number +9-kuijper. For each cultivar, the seed pieces were planted in boxes of $1 \mathrm{~m}^{3}$ with prepared soil as in the researches I and II, in a completely randomized design.

The origin and course of the bundles were determined with a WIID M3 stereoscopic microscope, by accompanying them from their origin, in the gemmar traces of the seed piece, and along the rhizome and the culm, to their end, in a terminal foliar trace, and by drawing them with the aid of a camera lucida, and, also, following the bundles in their descendent course, from a terminal foliar trace to their end, several nodes below.

These two researches produced the following results: (a) the peripheric fibrovascular system of the stem (rhizome and culm) originates from the periferic fibrovascular system of the seed piece; (b) the central fibrovascular system 
xxi.

of the stem (rhizome and culm) originates from both the peri feric and the central fibrovascular systems of the seedpiece; (c) the central bundles of the stem may originate also from the peripheric fibrovascular system of the rhizome or of the culm.

The researches III and IV revealed that the functionality of the nodal plexus depends upon the direction of the gradient of ripening of the axotropic bundles. Research III showed that in the intercalar meristem, the gradient of ripening of the axotropic bundles is centripetal on cv. CB 49-260, and centrifugal on CV. NA 56-79. This varietal difference winicin influences the time of the bud germination, depends essentially upon the presence of mature gemmar traces, and, in the centripetal ripening of the axotropic bundles, the first gemmar traces to ripe are the ones nearer the bud.

Research IV showed that the youngest germinant bud was that of the node +2 , on the CV. CB 49-260, authough apparently the centripetal ripening of its nodal plexus was completed only on the node +5 ; and, on $\mathrm{cv}$. NA 56-79, the young est germinant bud was that of the node +3 , although the centrifugal ripening of its nodal plexus was apparently completed on the node +2 . This fact seems to indicate thatalthough complete in its architectural arrangement in the node +2 , the nodal plexus on this cultivar did not yet have mature gemmar traces in this node.

Another varietal difference is that the fibro- 
xxii.

vascular architecture of the cataphylls is typical of each cultivar, being a taxonomic character of differentiation. 


\section{INTRODUÇÃO}

A presente pesquisa é uma continuação do estudo da arquitetura da rede fibrovascular nodal do colmo da cana-de-açúcar (Saccharum spp), que foi iniciada na dissertação de mestrado (AREVALO, 1983).

o estudo da arquitetura fibrovascular da canade-açúcar tem grande importância cientifica, sob $\circ$ ponto de vista anatômico, ou para se conhecer" 0 caminho da translocação de nutrientes e defensivos sistênicos que normalmente se aplicam nesta cultura.

Uma cuidadosa revisão bibliográfica mostrouque nenhum dos botânicos que estudaram a cana-de-açúcar tratou da sua arquitetura fibrovascular, embora alguns (ARTSCHWAGER, 1925; TANIMOTO, 1964) tivessem sugerido interpretações que não foram confirmadas (AREVALO, OP. cit.). Este fato se deve a que os referidos pesquisadores não dispunham de uma metodologia adequada para tais estudos, pois o método clássico, de estudos anatômicos, por meio de cortes seriados, exige interpre- 
tações muitas vezes extremamente difíceis e frequentemente sub jetivas, com riscos de conclusões errôneas ou duvidosas.

AREVALO (오. cit.), inspirado nos trabalhos de REEVES $(1946,1950)$ e de LAUBENGAYER (1949), desenvolveu o método microbiocelulolítico com o qual elucidou a arquitetú ra da rede fibrovascular nodal do colmo da cana-de-açúcar.

Este trabalho pretende: a) elucidar a arquitetura fibrovascular do caule (tolete, rizoma e colmo) da cana-de-açúcar, utilizando o método microbiocelulolítico; b) de terminar a posição do nó em que o plexo nodal já è funcional, em um cultivar precoce (NA 56-79) e em um tardio (CB $49-260)$.

Para estudar a arquitetura do sistema fibrovas cular do caule da cana-de-açúcar, foram formuladas duas hipóteses de trabalho:

a) A arquitetura fibrovascular do caule da cana-de-açúcar é diferente a de zea mays L. estudada por KUMAZAWA (1961).

b) Existem diferenças arquitetônicas fibrovasculares entre cultivares de cana-de-açúcar.

A fim de verificar a confirmação, ou não, das hipóteses referidas, foram planejadas as seguintes pesquisas:

I - Determinar a origem dos feixes fibrovascu lares no tolete, sua passagem para o rizoma e sua disposição arquitetônica no rizoma e no colmo. 
II - Determinar o curso descendente dos feixes centrais que emitem traços foliares terminais e laterais atra vês do colmo e suas possíveis conexões em seu trajeto.

III - Determinar a posição do nó em que o plexo nodal já é funcional, em um cultivar precoce (NA 5679) e em um tardio ( $C B$ 49-260).

$$
\text { IV - Determinar, pela germinação, o nó mais }
$$
jovem cujo plexo nodal já seja funcional, em um cultivar precoce (NA 56-79) e em um tardio (CB 49-260).

As pesquisas I, II e III foram realizadas usan do o método microbiocelulolítico e microscopia estereoscópica.

$\mathrm{Na}$ pesquisa IV, as avaliações foram realizadas em toletes individuais germinados. 


\section{REVISÃO DA LITERATURA}

A literatura referente ao assunto deste trabaTho já foi totalmente revisada e discutida por AREVALO (1983). Dos autores revistos, somente alguns referidos a seguir, apre sentam aspectos que merecem ser considerados.

ARTSCHWAGER (ㅇp. cit.) identificou dois sistemas fibrovasculares na cana-de-açúcar - o sistema periférico e o sistema central. Entretanto, na região nodal, onde os feixes e cordões se ramificam e se distribuem, ele não conseguiu determinar a correta configuração dos sistemas.

Em relação ao trajeto dos feixes fibrovascula res através dos internódios, esse autor confessa: "The large number of traces entering a leaf and the very complex nodal structure make it impossible to follow the course of the vascular bundles, except in the meristematic region of the stem apex"(...). "In regard to the length' of the individual leaf traces the same sequence is observed, that is, the largest bundles are also the longest, and pass independently through 
about eight internodes; Strasburger (16, p.328) found in Zea that the longest leaf traces pass through six internodes. In the sugar cane, the writer has followed a number of the large traces through seven and even eight internodes; their absolute length, however, he was unable to determine with certainty". Sobre o meristema intercalar, ele çiz: "The chief divergence from the normal structure consists in a transformation of the sclerenchyma bundle caps in a collenchyma and in a general reduction of the lignified cells of the vascular part of the bundle".

"Just as the center bundles become temporarily modified when passing through the intercalary meristem so the peripheral bundles in this region exhibit considerable deviation from the normal structure. The large peripheral bundes upon leaving the root zone and passing through the meristem be come so closely crowed that they appear like a honey comb in which the walls of the comb represent the parenchyma which se parates the bundles".

"The crowding of the bundles is the result of their increase in size, which is produced by the development of a huge collenchyma jacket around a small vascular nucleus (pl. 8)" .

KUMAZAWA (1961) divide os "cordões de traços foliares"de milho, em 3 tipos.

10 Tipo - Representado pelos cordões de traços foliares que seguem mais ou menos o curso interno e à altura 
de alguns nós mais abaixo, se encaminham para a periferia ejun tam-se com o sistema interno;

2o Tipo - Representado pelos cordões de traços foliares que chegam diretamente à posição dos feixes mais periféricos e se unem, mais cedo ou mais tarde, com eles;

3: Tipo - Representado pelos cordões que são muito pequenos e logo morrem dentro do cortex, ao nível do nó, ou próximo a êle.

Em relação aos traços gemares, KUMAZAWA afir.ma: ..."even if we can follow downward very exactly a few bundles of a lateral bud, a valid picture of the vascular relationship between the lateral bud and its mother axis cannot be obtained".

SHARMAN (1942), estudando milho, constatou que "se um cordão mediano é seguido para baixo da inserção foliar, ele se encaminha visivelmente para o centro do colmo, de onde desce, em curso vertical, por alguma distância, antes de se encaminhar para o lado oposto ao da sua entrada no colmo. Ele não vai para uma posição diametralmente oposta à do ponto de entrada, mas um pouco de um lado, e assim os cordões medianos de folhas de um lado cruzam-se com os das folhas do outro lado. Quando eles atingem a região periférica, descem en tre os laterais das folhas inseridas e opostas abaixo daquelas de onde eles derivaram. O cordão, finalmente se une com um desses laterais".

AREVALO (op. cit.) constatou que os feixes fi- 
brovasculares da cana-de-açūcar estão distribuidos em doissis temas de feixes axótropos e um sistema de feixes plagiotropos. Os sistemas são os seguintes:

a) Sistema periférico - constituía de cordões de feixes axótropos periféricos que percorrem toda a extensão periférica do caule, ramificando-se nas regiões nodais, em traços foliares periféricos, traços gemares periféri cos, traços radiculares e ramos de interconexão.

b) Sistema central - constituído de feixes axō tropos que percorrem toda a extensão do caule em sua região central, ramificando-se nas regiões nodais em traços foliares centrais (terminais e laterais); traços gemares centrais e ramos de interconexão.

As ramificações plagiotrópas dos dois sistemas, interconectadas entre si,formam $\circ$ plexo nodal, que $e \circ$ sistema de feixes plagiótropos. 
8.

\section{MATERIAIS E METODOS}

Este trabalho foi realizado na Escola Superior de Agricultura "Luiz de Queiroz", da Universidade de São Pau10, Piracicaba, Brasil, em 1983-84. Compreende as seguintes pesquisas:

3.1. Pesquisa I - Determinar a origem dos feixes fibrovasculares no tolete, sua passagem para o rizoma, e sua disposição arquitetônica no rizoma e no colmo.

Foram plantados em caixas de $1 \mathrm{~m}^{3}$ de capacida de, cheias de solo composto (areia + solo argiloso + serapilheira, em partes iguais), 26 toletes +10-Kuijper de cada um dos cultivares NA 56-79 e CB 41-76. As plantas que se desenvolveram desses toletes, foram cultivadas du rante 4 meses. Nos 3 primeiros meses, elas receberam ir- 
rigação diāria e, durante 04 : mês, foram mantidas em estres se hidrico, para o envelhecimento precoce.

o crescimento em estado de estresse hídrico

foi obtido regando-se as plantas somente quando apresentavam início de murchamento, o que ocorria aproximadamente em inter valos de uma semana.

o método de envelhecimento precoce foi usado com dois objetivos: a) conseguir-se colmos relativamente curtos, com maior número de internódios, para facilitar a manipulação do material, em laboratório; b) obter-se, precocemente, o amadurecimento dos meristemas intercalares dos internódios superiores, de modo que eles não se desintegrassem pela celulolisação, fato este que dificulta o acompanhamento da trajetória dos feixes através dos internódios mais novos.

Esses colmos, com toletes, foram colhidos e levados ao laboratório, partidos longitudinalmenteao meio, e tratados por 10 minutos com água fervente, para evitar o brotamento e o crescimento irregular, durante o processo de celulolisação. $t$

Depois de esfriados, os meios-colmos foram pos tos a celulolisar em caixas retangulares, de ferro, pintadas com tinta anti-ferrugem.

Sobre os meios colmos foi derramada uma suspen são de inoculante microbiocelulolitico preparado segundo AREVALO (1983). 
Todo o material assim preparado foi mantido em laboratório à temperatura ambiente ( $\pm 229 \mathrm{C})$. As colônias do inoculante se desenvolveram rapidamente. Em 10 dias todos os meios-colmos estavam recobertos por elas. Semanalmente, eram substituídos os resíduos da celulolisação por iguais volumes de uma solução nutritiva especial (AREVALO op. cit.).

Após cerca de 50 dias, a celulolisação estava completada. O material foi então lavado em āgua de torneira, embrulhado em jornal, etiquetado e conservado em congelador, para exames posteriores.

Os estudos foram realizados por observações e desenhos do material, - em microscópio estereoscópico marca WILD M3, provido de câmara clara intercalada.

3.1.1. Numeração de colmos e rizomas - A numeração ado tada até agora tem sido a de kuijper (1915), que consi dera o 19 nó no ápice do colmo. Entretanto, essa notação não diferencia os gomos do colmo dos do rizoma. Para maior clare za didática. neste trabalho, foi adotado o critério de se man ter a notação de Kuijper para o colmo, mas numerar o rizoma em sentido contrário, isto é, a partir de sua base, no tolete. Nessas condições, o primeiro gomo formado na cana está localizado na base do rizoma (19 nó + 19 internódio). Portan to, o rizoma da Figura 3 contém 2 gomos. Por sua vez, o colmo, numerado de acordo com a notação de kuijper, contém 6 gomos. 
11.
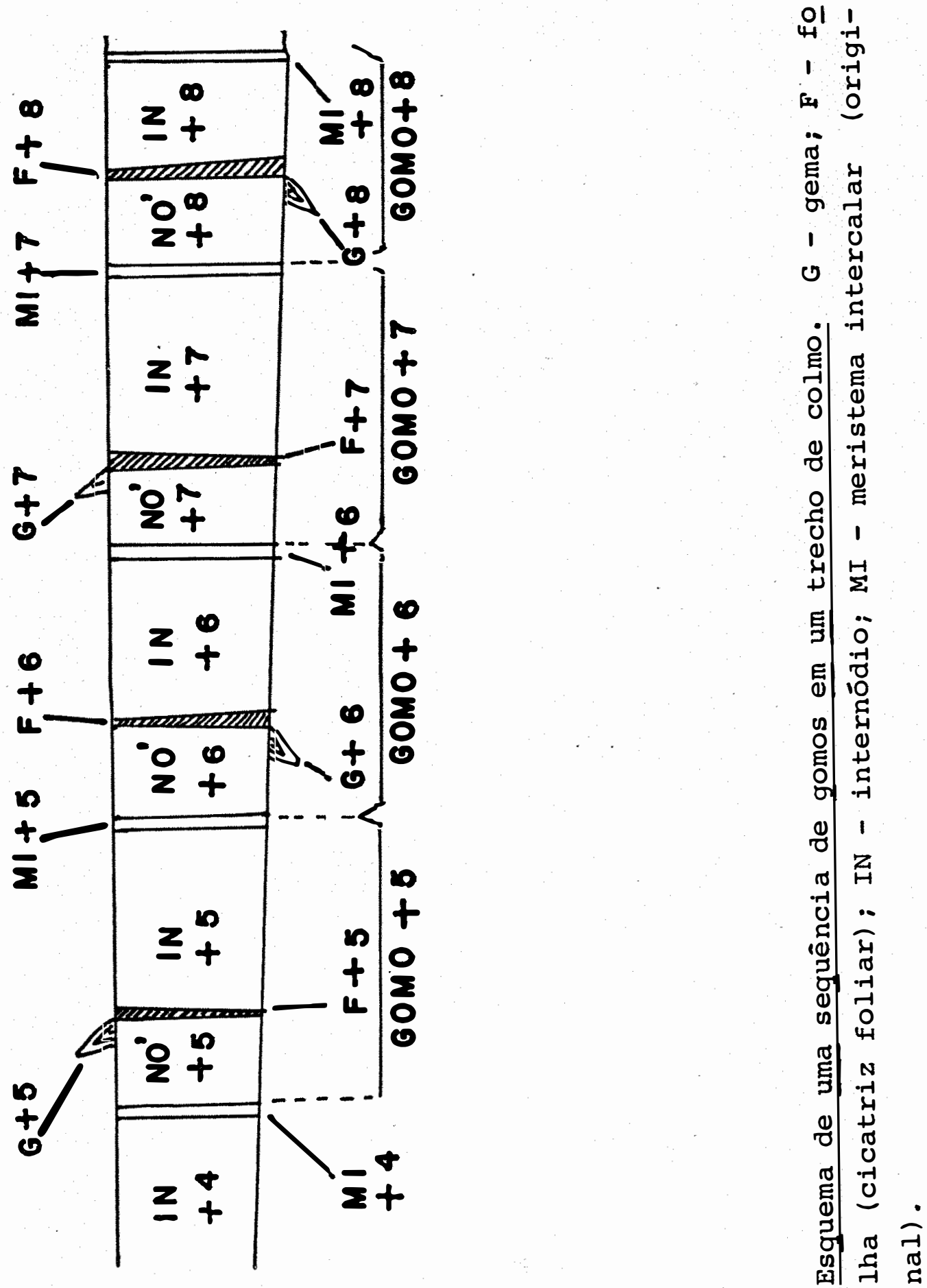

त्- 
3.2. Pesquisa II - Determinar o curso descendente dos feí xes centrais que emitem traços foliares terminais e laterais através do colmo, e suas possíveis conexões em seu trajeto.

Foram cultivados até a idade de 18 meses, em estresse hídrico, 26 plantas de cada um dos cultivares NA 5679 e $C B$ 41-76.

De cada cultivar foram tonados 25 colmos, partidos ao meio e tratados como na pesquisa $I$.

A numeração das folhas (cicatrizes foliares) dos nós, dos internódios, das gemas e dos meristemas intercalares, obedecem ao sistema de Kuijper (1915). Por este sistema, cada unidade morfológica do colmo é constituída do conjunto de 1 nó + o internódio imediatamente inferior. Esta unidade morfológica é o gomo. Todos os elementos morfológi cos de um gomo recebem o mesmo número. O esquema da Figura 1 ilustra o sistema.

Os trechos dos colmos estudados abrangem, respectivamente, 17 internódios e 15 nós no cv. NA 56-79, e 18 internódios e 16 nós no cv. CB 41-76.

3.3. Pesquisa III - Determinar a posição do nó em que o plexo nodal, já é funcional em um cultivar precoce (NA 56-79) e em um tardio (CB 49-260).

Tomar, de cada cultivar, 5 grupos de toletes 
uninodais, do nó +1 ao +9-Kuijper, partí-los longitudinalmente, ao nivel da gema e colocá-los a celulolisar; após a celulolisação, tratá-los como na Pesquisa $I$, e conservar o material em congelador, para exames posteriores.

\subsection{Pesquisa IV - Determinar, pela germinação, o nó mais jovem, cujo plexo nodal já seja funcional, em um cul- tivar precoce (NA 56-79) e em um tardio (CB 49-260).}

Delineamento experimental de blocos inteiramen te casualizado.

Foram tomados 8 colmos ( 8 repetições), cada um dos quais foi dividido em 10 toletes de uma gema, a partir do tolete zero até o tolete +9-Kuijper, e colocados para germinar em caixas contendo solo preparado ( $1 / 3$ solo argiloso + $1 / 3$ areia $+1 / 3$ serapilheira).

Foram usados colmos de 5 meses de idade, para ambos os cultivares.

A avaliação dos resultados foi feita com base no número de plântulas emergidas na superfície do solo, 30 dias após o plantio. 


\section{RESULtadOS}

Os resultados das pesquisas realizadas neste trabalho serão relatados a seguir.

\subsection{Pesquisa $I$ - Determinar as origens dos feixes fibro- vasculares no tolete, sua passagem para o rizoma e sua disposição arçuitetônica no rizoma e no ccimo.}

A Figura 2 mostra um esquema de uma touceirajo vem de cana-de-açūcar, originada de uma gema do tolete, vendo se o colmo primārio e dois colmos secundários. Na base desses colmos estão os respectivos rizomas.

4.1.1. Origem dos sistemas fibrovasculares em NA 56-79

A Figura 3 mostra, no tolete (T), a origem dos 


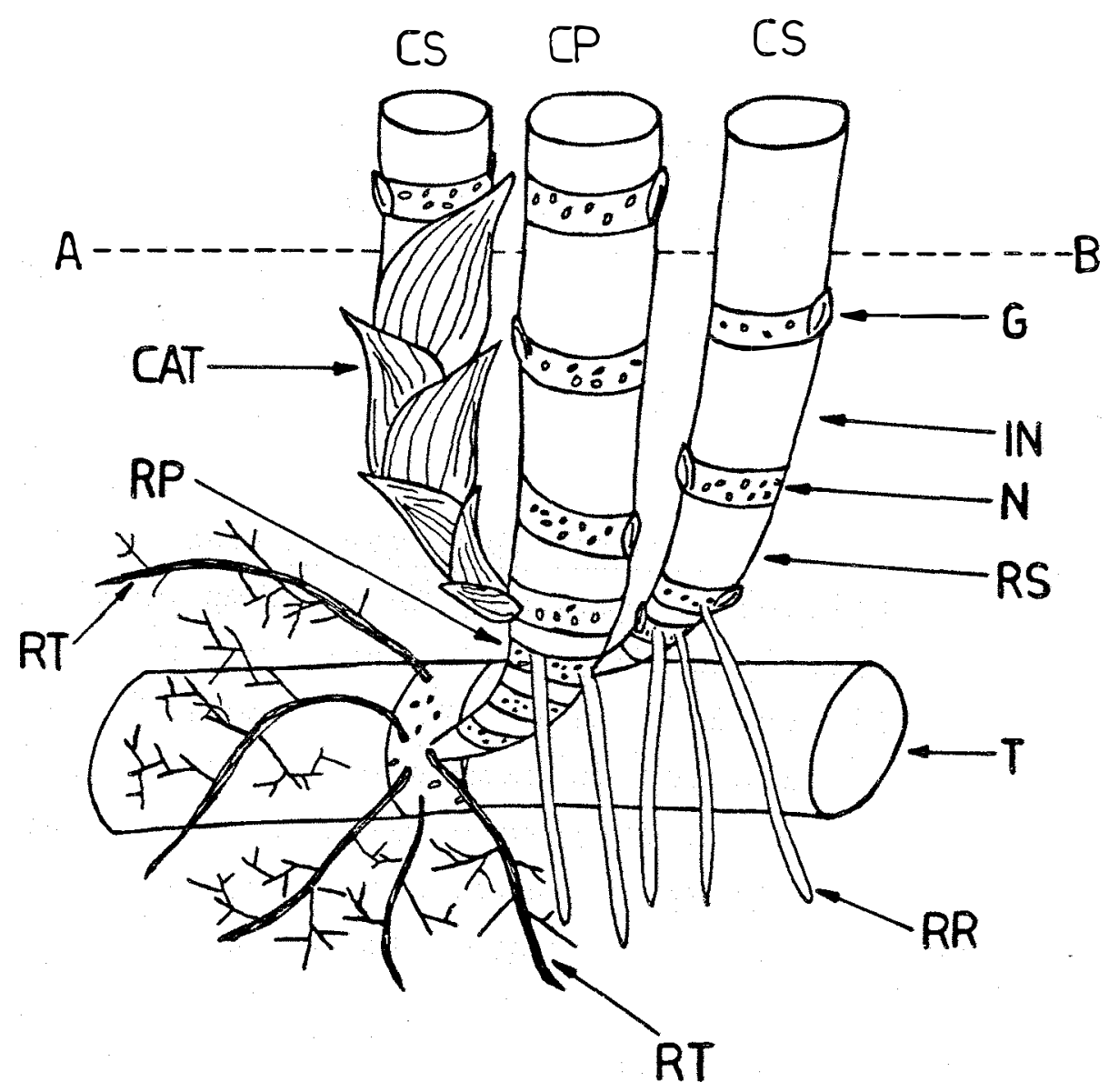

15.

Figura 2. Esquema de uma touceira em formação. T - tolete; CP - colmo primário; CS - colmo secundário; N - nó; G - gema; IN - internódio; RR - raízes do rizoma; RT - raízes do tolete; RP - rizoma primário; RS-rí zoma secundário: CAT - catafilos; $A B$ - nível do so 10.

dois sistemas fibrovasculares que percorrem o rizoma ( $R P)$ e o colmo (CP)-o sistema periférico e o central.

Um exame geral do conjunto fibrovascular mostra que o feixe central $F C_{1}$, do tolete, emite um traço gemar $\underline{\text { (tgca) }}$ que penetra no rizoma, originando o feixe central sca, 


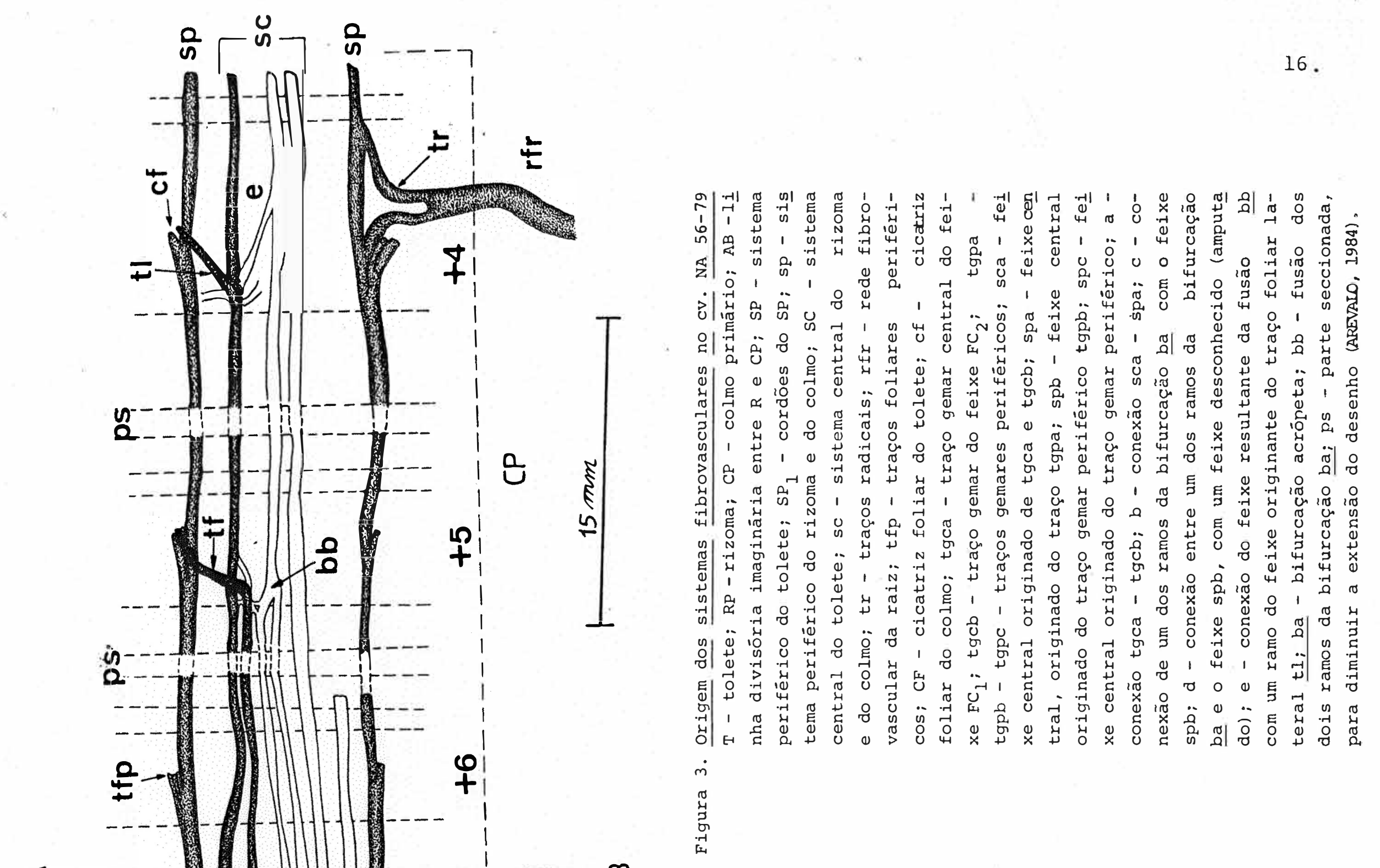


o qual se estende ao longo do rizoma e do colmo. Ainda, no tolete, o traço gemar tgca recebe, em conexão (a) um traço ge mar $\underline{\text { (tgcb) }}$ do feixe central $F_{2}$, já no primeiro nó do rizoma. O feixe sca recebe, em conexão (b), o feixe spa, originado de um traço gemar periférico (tgpa). Em seguida, ele se bifurca acrópetamente (ba). Um dos ramos dessa bifurcação recebe, em conexão (c), um feixe (spb), originado do traço gemar periférico tgpb, docordão $\mathrm{SP}_{1}$. No segundo nó do rizoma, ele recebe em conexão (d), outro feixe, de procedência desconhecida (ạn putado. Então, os dois ramos da bifurcação do feixe scapas sam para o colmo (linha $A B$ ). No nó +5 , do colmo, esses dois ramos da bifurcação ba se fundem novamente, formando uma bifurcação basipeta (bb). O feixe resultante dessa fusão contí nua seu curso colmo acima. No nó +4 , ele recebe, em conexão (e), um ramo do feixe central que emite o traço foliar lateral $(t)$.

O feixe central $\mathrm{FC}_{2}$, do tolete, emite traços gemares que seguem trajetórias similares mas foram cortados para clareza da figura. Esse feixe $\mathrm{FC}_{2}$ ramifica-se axotrópicamente no tolete, produzindo dois ramos que se anastomosam: um, adaxial, não ramificado, e outro, abaxial, ramificado, me se anastomosa (므) em vários pontos com 0 cordão $\mathrm{SP}_{1}$ do siste ma periférico do tolete.

O cordão $\mathrm{SP}_{1}$, na mesma região das conexões com - feixe $\mathrm{FC}_{2}$, emite numerosos traços gemares, que originam fei xes centrais e cordões periféricos, no rizoma. 
O sistema periférico do tolete $\left(\mathrm{SP}_{1}\right)$ emite trą ços gemares periféricos originantes de feixes que vão compor tanto o sistema periférico ( $\underline{\mathrm{sp}}$ ) como o central ( $\underline{\mathrm{sc}}$ ) do rizoma e do colmo.

Nota-se, na Figura 3, que o traço gemar tgpc, do cordão $\mathrm{SP}_{1}$, do tolete, originou o feixe central spc. Este feixe bifurcou-se acrópetamente (ba) e originou, em um de seus ramos, o traço foliar terminal tf e no outro, o traço fo liar lateral tll. Portanto, esses dois traços foliares têm origem ontogênica no sistema periférico do tolete.

Os feixes do sistema central do tolete $\left(\mathrm{FC}_{1}\right.$ ' $\mathrm{FC}_{2}$ ) produzem traços gemares centrais, que vão originar somen te feixes do sistema central ( $\underline{\text { sc })}$ do rizoma e do colmo. Por exemplo, o traço gemar central tgca, do tolete, conecta-se com outro traço gemar também central, tgcb, no ponto a, originando o feixe central sca no rizoma. Entretanto, no ponto $\underline{b}$, ele recebe, em conexão, o feixe spa, procedente do traço gemar pe riférico tgpa. Este feixe central é, por conseguinte, formado de componentes vasculares originados tanto do sistema central co mo do periférico do tolete.

A Figura 4 mostra um aspecto geral da organiza ção arquitetônica dos sistemas fibrovasculares do rizoma primário do cultivar NA 56-79. Em sua base, permanece a parte do tolete $(\mathrm{T})$ que contém os elementos formadores dos sistemas fibrovasculares do rizoma primário (RP). 


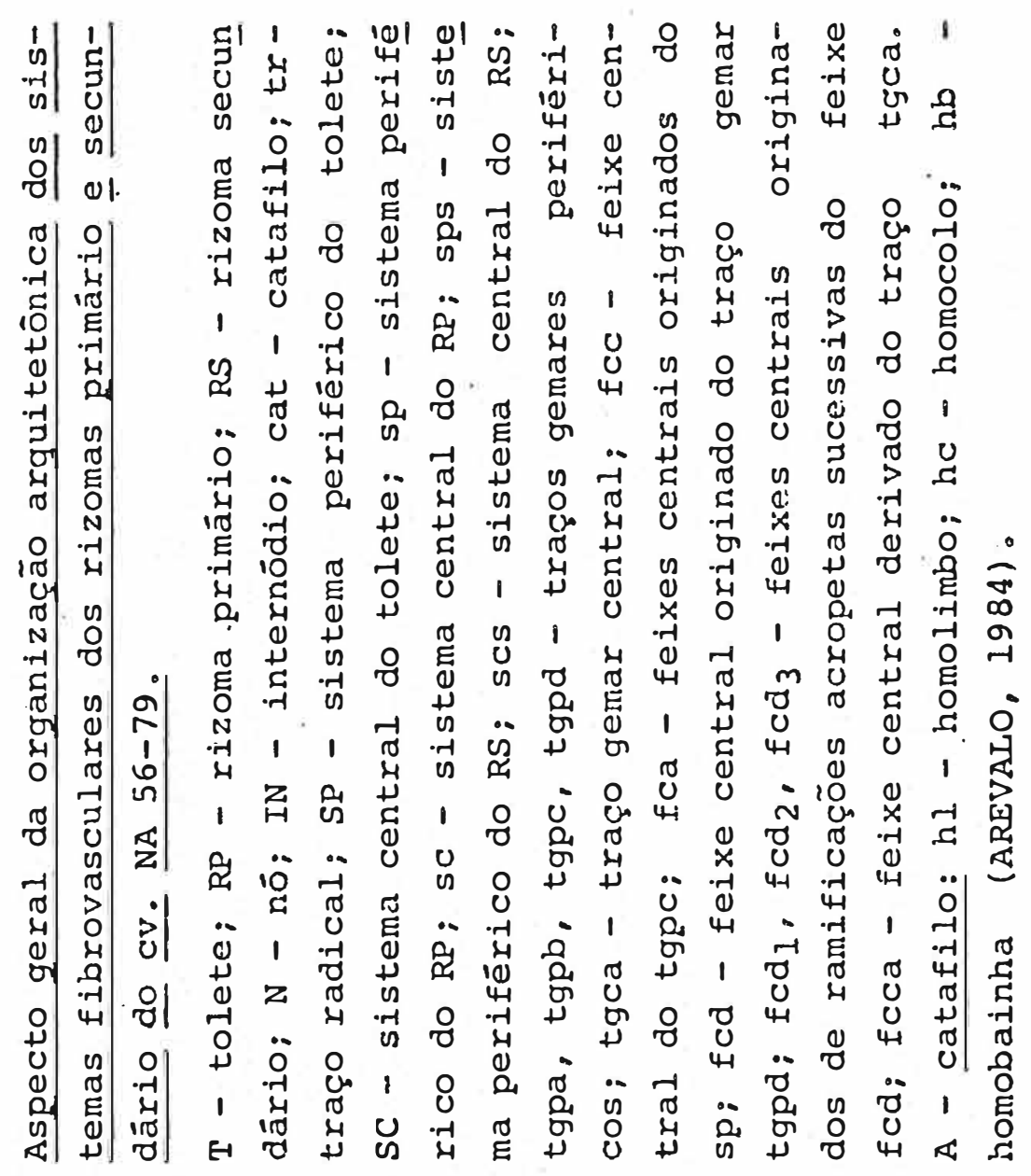

म

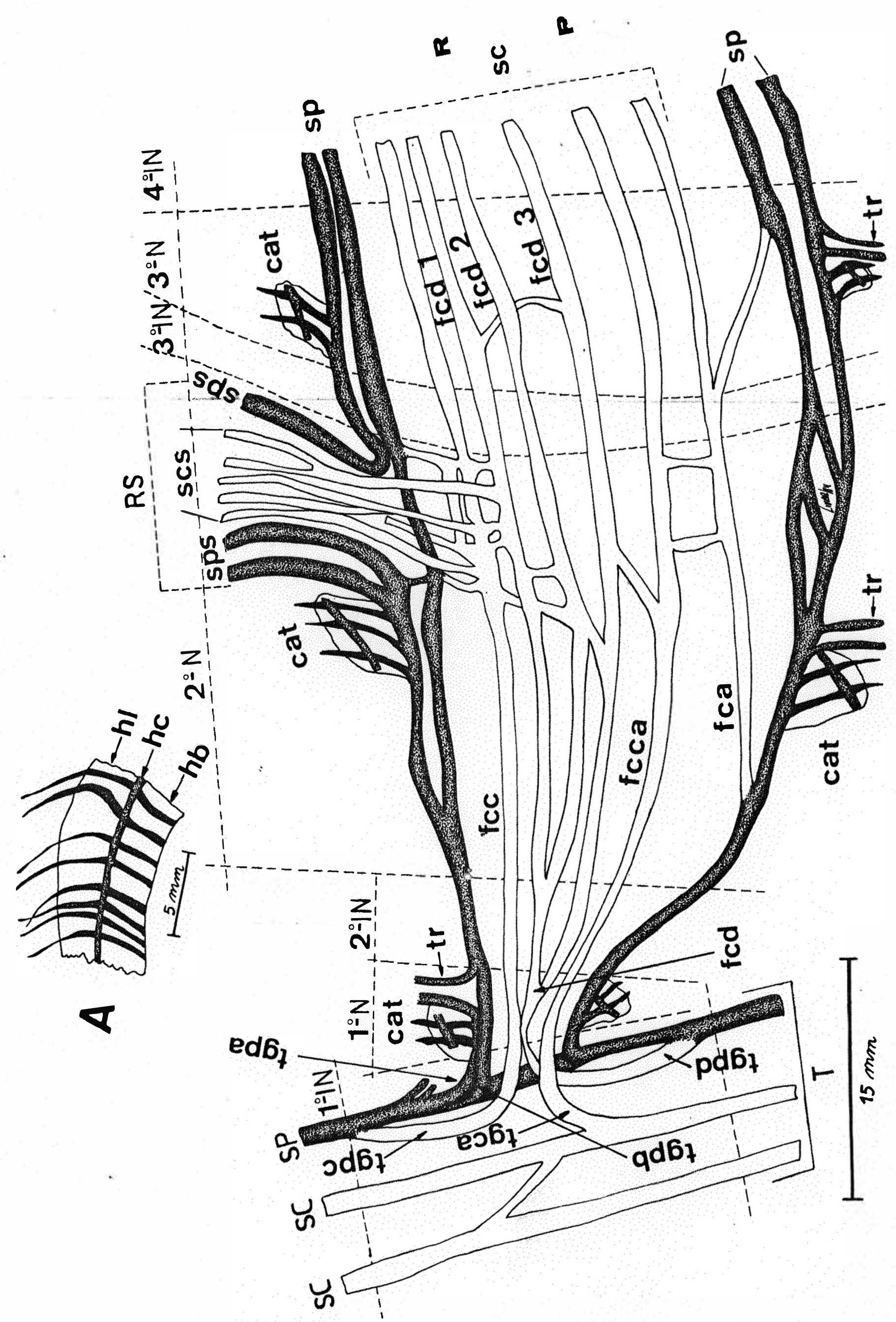


No segundo nó do $\mathrm{RP}$, nasce uma ramificação que é a base de um rizoma secundário (RS). Os três nós do RP apre sentam catafilos (cat) e traços radicais (trr).

Tanto os cordões plurifasciculados do sistema periférico (sp), como os feixes do sistema central (sc) do RP, originam-se de traços gemares do sistema periférico (SP) e de traços gemares de feixes do sistema central (SC), do tolete. Esta organização não se repete no RS, no qual os dois sistemas fibrovasculares se originam, respectivamente, de traços gemares dos sistemas periférico e central do RP.

Como já foi observado, no estudo da Figura 3, também aqui, o sistema periférico do tolete (SP) produz traços gemares periféricos (tgpa, tgpb), que originam os cordões periféricos do RP. O mesmo sistema periférico do tolete produz traços gemares (tgpc, tgpd) que dão origem a feixes do sistema central (sc) do RP. Além disso, os feixes (f́ca) do sistema central do RP podem ter origem também, de ramificações de cordões do sp, em qualquer altura do rizoma ou do coll mo (Figura 3). O traço gemar periférico tgpc do tolete origina o feixe central Ecc do RP. O traço gemar periférico tgpd do tolete origina o feixe central fcd. Este feixe por sucessivas bifurcações produz os feixes centrais $\mathrm{fcd}_{1}, \mathrm{fcd}_{2}$ e $\mathrm{fcd}_{3}$ do $(\underline{s c})$.

Os feixes (SC) do sistema central do tolete, emitem traços centrais (tgca), que originam feixes do sistema central (fcca) do RP. 
4.1.2. Origem dos sistemas fibrovasculares em $C B$ 41-76

A Figura 5 mostra, no tolete, a origem dos dois sistemas fibrovasculares que percorrem o rizoma e o colmo - o sistema periférico ( $\mathrm{sp}$ ) e o sistema central (sc).

De acordo com a notação adotada (3.1.1) o primeiro gomo formado está localizado na base do rizoma (IN+N). Neste caso, como se vê, o rizoma só tem l gomo, e o colmo tem 5 gomos $(+5 a+9)$.

Um exame geral do conjunto fibrovascular mostra que o traço gemar periférico (tgpa) do cordão $\mathrm{SP}_{1}$, produz - feixe spa que penetra no rizoma bifurcando-se na sua base (ba), e originando dois feixes centrais $f_{1}$ e $f_{4}$, que percor rem toda a extensão do rizoma e do colmo. Um desses feixes termina no nó +5 produzindo o traço foliar terminal $\left(t f_{1}\right)$. o outro feixe $\left(f_{4}\right)$ ainda no nó do rizoma, recebe, em conexão (a) um curto feixe (sca), originado do traço gemar central (tgca) do feixe central FC 1 do tolete. Após a conexão no ponto a o feixe $\mathrm{f}_{4}$, percorre toda a extensão do rizoma e do colmo acima do nó +4 .

o outro traço gemar periférico (tgpb) também do cordão $\mathrm{SP}_{1}$, origina um feixe $\underline{\mathrm{spb}}$ que passa a compor o sistema periférico (sp) do rizoma e do colmo. Este bifurca - se (b) , produzindo um cordão periférico e um feixe central ( $f_{2}$ ). o cordão periférico continua, ao longo do colmo, produzindo traços radicais $(t r)$ e traços foliares periféricos (tfp). 


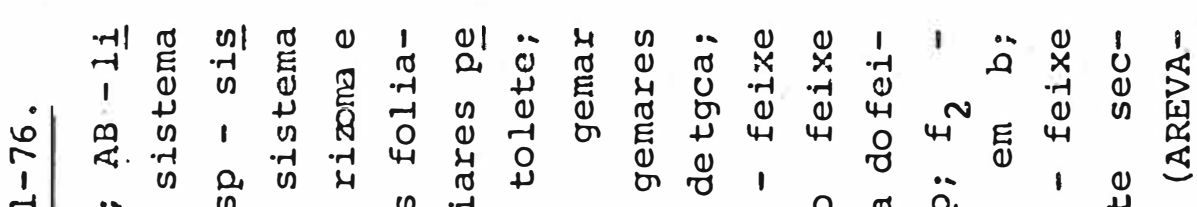

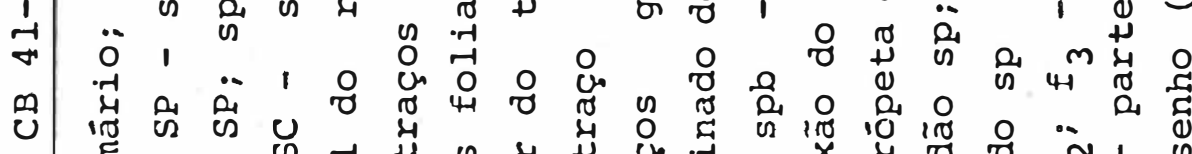

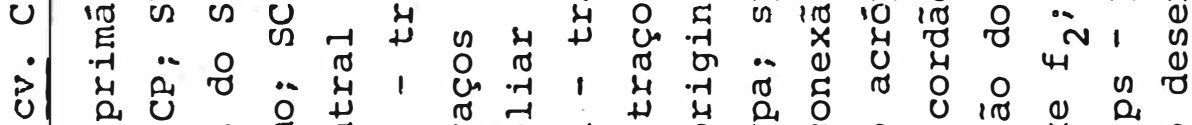

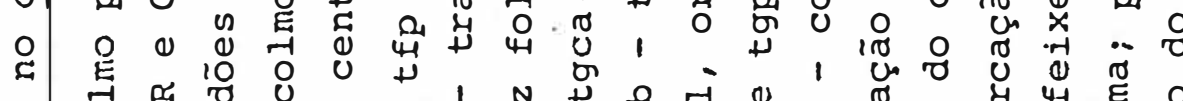

忽

मू.

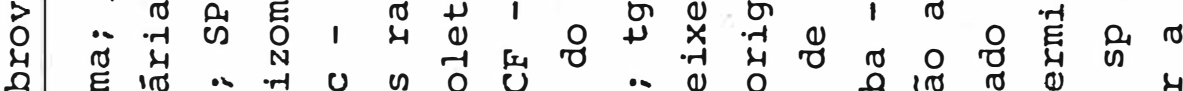

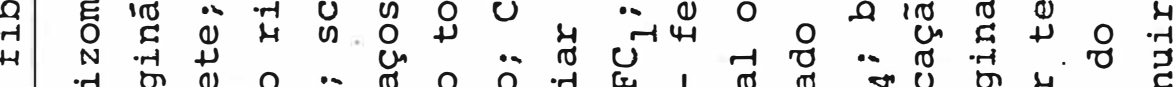

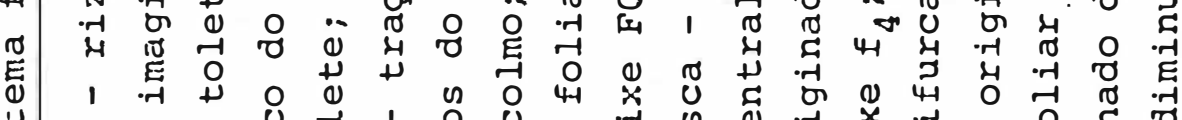

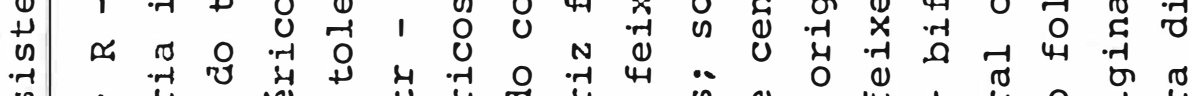

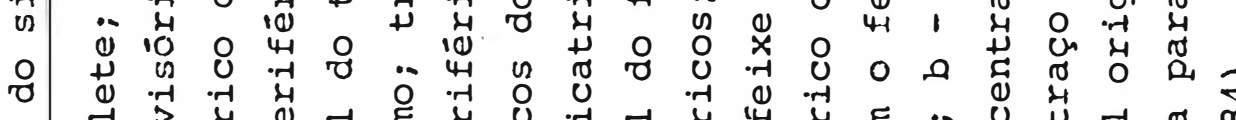

E

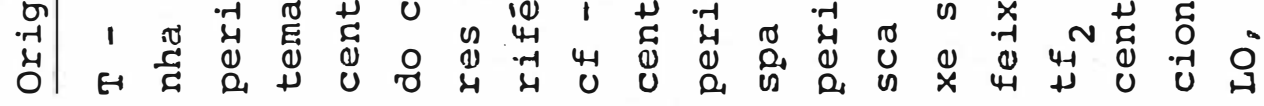

i

落

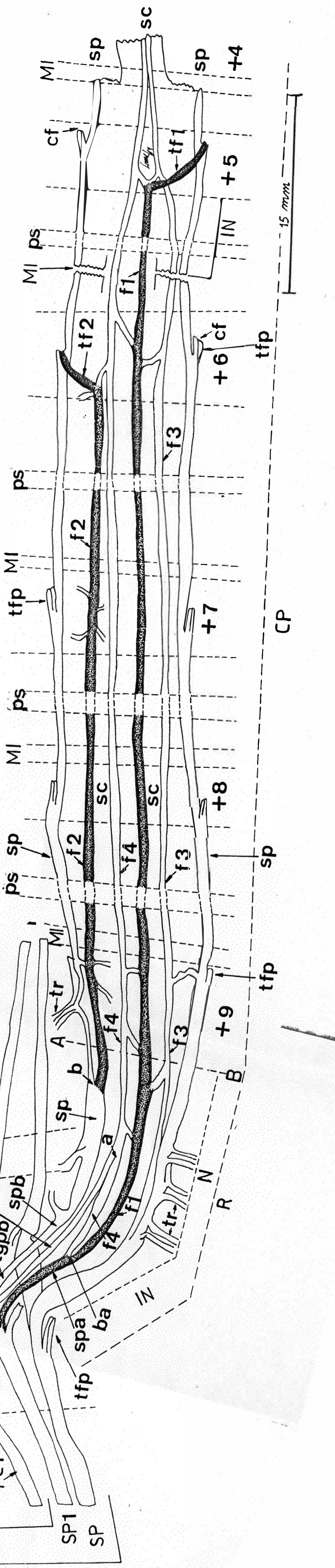

22. 
O feixe central $\left(f_{2}\right)$ continua seu curso, através do colmo, terminando em um traço foliar terminal $\left(t f_{2}\right)$ no nó +6 .

O sistema periférico do tolete (SP) emite traços foliares periféricos ( $t f p$ ) e penetra no rizoma, formando o seu sistema periférico (sp), o qual continua no colmo. No rizoma, ele emite traços radicais (tr) e, no colmo, traços foliares periféricos (tfp). No rizoma, ele emite um feixe œn tral $\left(f_{3}\right)$, o qual continua seu curso, através do colmo, para além do nó +5 . Ainda no rizoma, ele emite traços radicais (tr).

A Figura 6 mostra um aspecto geral da organiza ção arquitetônica dos sistemas fibrovasculares do rizoma primário (RP) e secundário (RS) do Cv. $C B$ 41-76. Na sua base, permanece a parte do tolete contendo os elementos formadores dos sistemas fibrovasculares desse RP. 'Nó 29 nó se nota uma ramificação, que é a base do rizoma secundário (RS) que dalí se desenvolve. Nos dois nós do RP, notam-se os catafilos(cat) e, no 2 : nó, os traços radicais (tr).

Tanto os cordões plurifasciculados do sistema periférico $(\underline{s p})$ como os feixes do sistema central $(\underline{s c})$, do RP, originam-se de traços gemares do sistema periférico (SP) do tolete e de traços gemares centrais dos feixes (SC) do sistema central do tolete.

A formação dos sistemas fibrovasculares do RS é idêntica à do cv. NA 56-79, em que esses dois sistemas fibrovasculares originam-se, respectivamente, de traços gemares dos sistemas periférico e central do RP. 


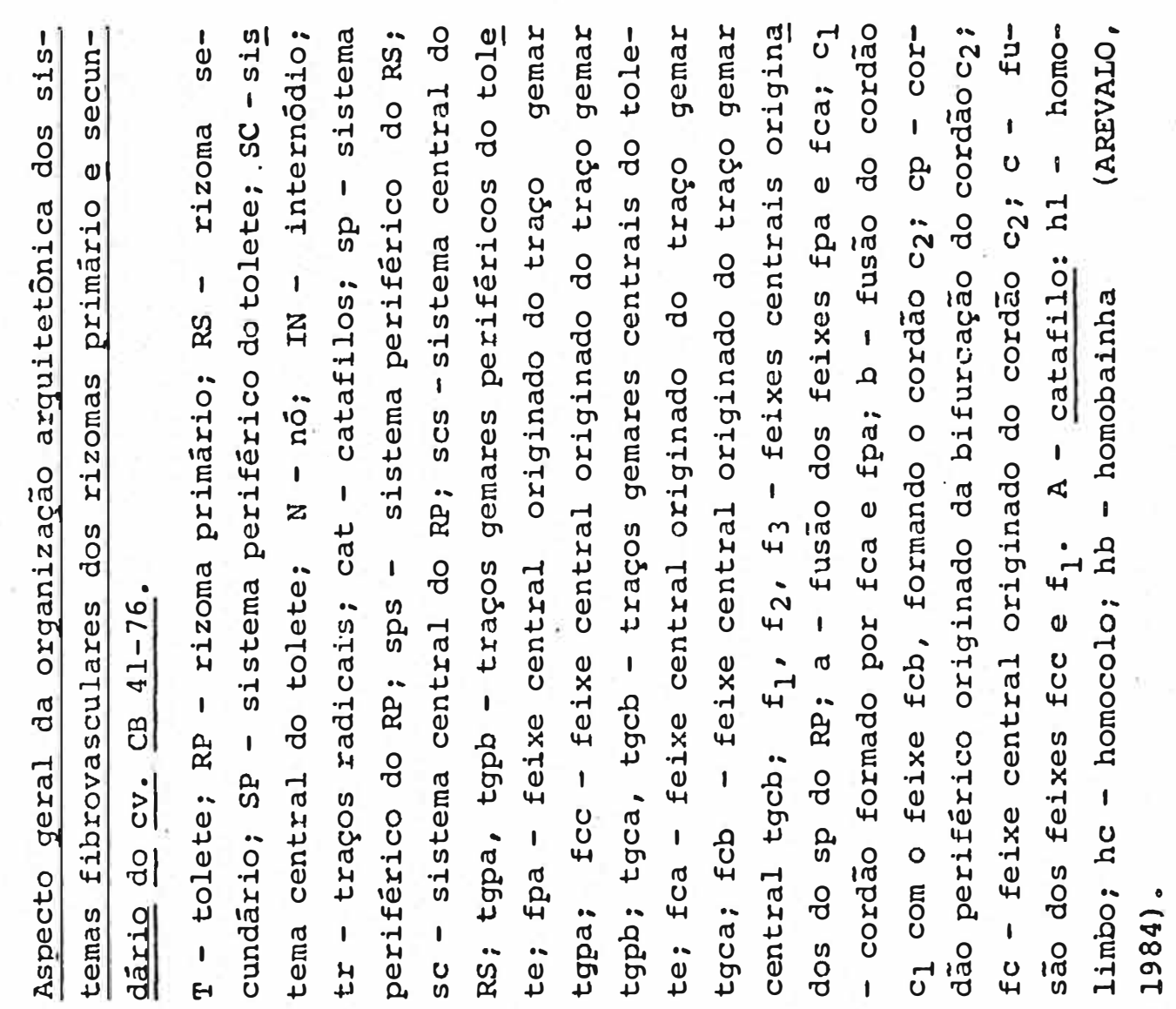

得|

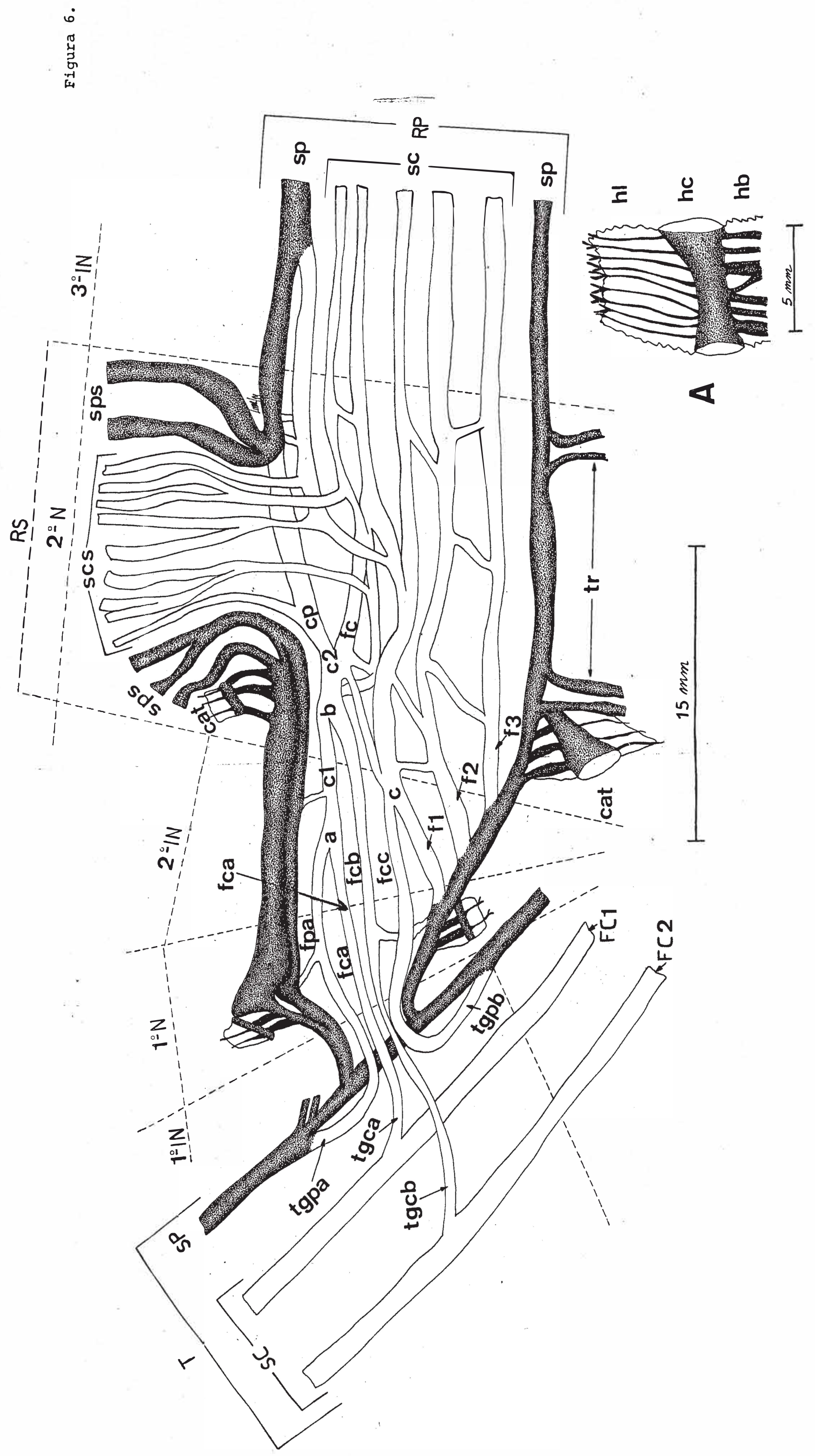


O sistema periférico (sp) do RP é originado de cordões provenientes de ramificações do SP do tolete. 0 mesmo sistema periférico do tolete produz traços gemares ( tgpa, tgpb) que dão origem a feixes (fpa, fcc) do sistema central

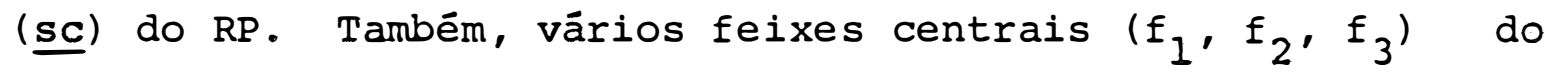
$R P$, originam-se de ramificações de cordões do $\underline{s p}$, em diversas alturas do rizoma, ou do colmo.

Um exame da organização fibrovascular na inser ção do RP mostra outros aspectos interessantes, relacionados com o seu sistema central. O traço gemar tgpa, do SP, produz o feixe central fpa e o traço gemar central tgca, do SC, produz o feixe central fca, que se funde com $0 \underline{f p a, ~ e m ~} \underline{a}$, for mando o cordão $\underline{c}_{1}$; o traço gemar central tgcb produz o feixe central $\underline{f c b}$, que se funde em $b$, com o cordão $\underline{c}_{1}$, originando 0 cordão $\underline{c}_{2}$, que se bifurca em um cordão periférico (cp) e um feixe central (fc). Ambos produzem traços gemares centrais (scs) do RS. O traço gemar periférico tgpb, do tolete, pro

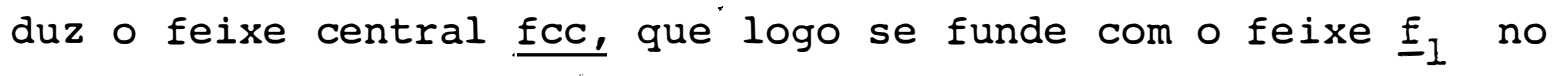

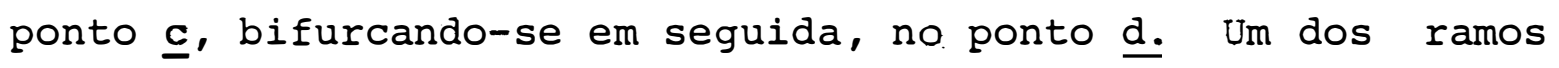
desta bifurcação produz traços gemares centrais do scs, do RS.

\subsubsection{Catafilos}

Os catafilos se localizam nos nós dos rizomas nas mesmas posições que as folhas. (Figura 7). Como folhas 
atrofiadas que sao, apresentam, também, as partes homólogas das folhas, que podem ser designadas por homobainha (hb), ho mocolo (hc) e homolimbo (hl) em homologia respectiva com a bainha, o colo e o limbo da folha.

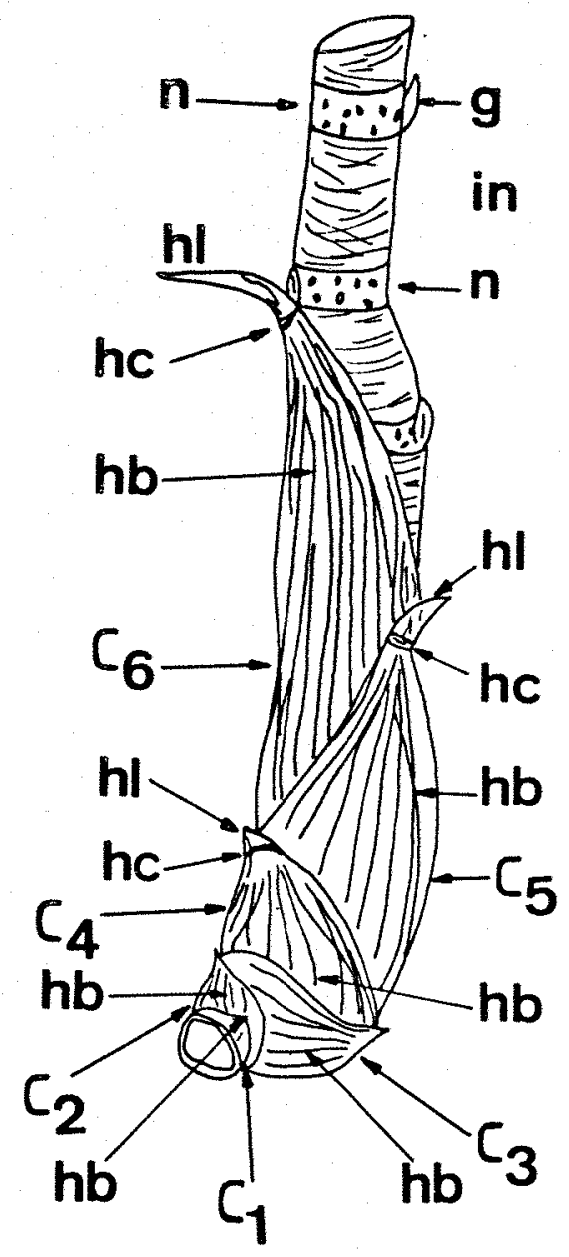

Figura 7. Esquema de um rizoma mostrando a evolução dos catafilos. $C_{1}$ - 19 catafilo (profilo da gema); $C_{2}, C_{3}$, $\mathrm{C}_{4}, \mathrm{C}_{5}, \mathrm{C}_{6}$ - catafilos progressivamente evoluidos, nos nós acrópetamente sucessivos; hb - homobainha; hl - homolimbo; hc - homocolo; n - nó; in - inter nódio; g - gema (AREVALO, 1984). 
A atrofia máxima ocorre nos catafilos da base do rizoma. Neste só existe a homobainha (hb). $\AA$ medida que os catafilos se localizam nos nós mais superiores do rizoma, vai se desenvolvendo o homolimbo (hl) e evidenciando-se o homocolo (hc).

Como a folha, o catafilo é paralelinervio, mas seu sistema fibrovascular é extremamente lignificado. Os tecidos parenquimatosos que formam o corpo laminar do catafilo tornam-se lignificados, mantendo o aspecto membranáceo que o caracteriza. A homobainha, que é mais espessa do que o homolimbo, tem uma consistência coriácea frágil.. A fragilidade, provavelmente, se deve ao paralelismo do seu sistema fibrovascular. O homolimbo, mais pergamináceo, é muito frágil, pela mesma razão.

Entre a homobainha e $\circ$ homolimbo, existe $\circ$ homocolo. O colo da folha, também conhecido como colarinho, em botânica da cana-de-açúcar, é uma região altamente colenquima tosa, cuja espessura é bem maior do que a da bainha e do limbo. No catafilo, o homocolo também é muito mais espesso do que a homobainha e o homolimbo, sendo altamente esclerificado, formando um travessão entre a homobainha e o homolimbo. No material celulolisado, o homolimbo não reveste as extremidades apicais dos feixes fibrovasculares nervurais. Os bordos superiores do catafilo, nessas condições, apresentam um aspecto ciliado (Figura 4A; Figura 6A).

Os catafilos dos cVs. NA 56-79 e CB 41-76, 
apresentam notáveis diferenças morfológicas nos seus sistemas fibrovasculares.

No $\mathrm{CV}$. NA 56-79 (Figura 4A), a densidade dos feixes fibrovasculares nervurais da homobainha são aproximadamente de 6 feixes por $5 \mathrm{~mm}$ de largura. No CV. CB 4I-76, eles são mais unidos entre si, com uma densidade aproximada de 7 feixes por $5 \mathrm{~mm}$. Esta observação é apenas qualitativa, mas merece uma determinação acurada estatisticamente, pois é, sem dúvida, um caráter taxonômico importante, de diferencia ção destes dois cultivares.

O homolimbo do cultivar NA 56-79 abrange cerca de metade do comprimento dos feixes. Seus feixes nervurais são vigorosos, afilando-se para a ponta e assemelhando-se a bordo ciliado, com cilios longos. No Cv. CB 41-76 (Figura 6A), O homolimbo abrange praticamente o comprimento total dos feixes. Seus feixes nervurais, embora em continuação aos da homobainha são muito delgados, terminando, cada um deles em uma jreve bifurcação cujos ramos curtos formam o bordo ciliado, com cilios muito curtos.

O homocolo do cultivar NA 56-79 é muito estrei to, de forma aproximadamente cilíndrica, com uma barra de diạ metro aproximadamente igual ao dos feixes, e muito lignifica da. No Cv. CB 41-76 (Figura 6A), o homocolo é extraordinaria mente desenvolvido e lignificado, com a forma de um travessão bicôncavo, de secção elíptica. Seu diâmetro maior equivale a aproximadamente, 5 diâmetros dos feixes fibrovasculares nervu 
rais da homobainha. Esta medida è apenas qualitativa, parase dar uma idéia da ordem de grandeza do diâmetro do travessão, não tendo sido feita qualquer amostragem.

Os catafilos originam-se de traços catafilares, emitidos pelos cordões periféricos do rizoma.

4.2. Pesquisa II - Determinar o curso descendente dos feixes centrais, que emitem traços foliares terminais, e laterais através do colmo, e suas possíveis conexões em seu trajeto.

Os resultados finais desta pesquisa estão mostrados nas Figuras 8 e 9 , que apresentam um trecho de colmo de cada um dos cvs. NA 56-79 e CB 41-76, com 18 meses de idade, totalmente celulolisados. Nas figuras, estão destacados apenas alguns feixes típicos e traços foliares representativos, além dos demais elementos morfológicos, tais como gemas, cicatrizes foliares, e raízes.

\subsubsection{Sistema perifērico}

O sistema periférico (sp), è formado de cordões fibrovasculares plurifasciculados, localizados na região periférica do colmo.

Em certos nós $(+19,+12 .,+10,+9,+8$, na Figu- 
ra $8 ;+18,+16 ;+13$, na Figura 9), dos cordões periféricos derivam feixes que vão fazer parte do sistema central.

Nos trechos de colmos descritos, alguns desses feixes centrais terminaram em nós, ramificando-se nas suasextremidades. Dessas ramificações terminais, algumas se conectam com feixes centrais, e a mais desenvolvida delas forma um traço foliar terminal (na Figura 8: nó +8, tf $f_{2}$ etf 3 ; nó +5, tf 1 ; na. Figura 9: nó $+6, t f_{2}$; nó $+5, t f_{1}$ ).

Do sp derivam tamkém os traços foliares periféricos, visíveis na cicatriz foliar (cf), que vão formar as pequenas nervuras da bainha, e os traços gemares periféricos, que originarão o sistema periférico das ramificações do colmo, pelo desenvolvimento das gemas (AREVALO, 1983).

\subsubsection{Sistema central}

Os feixes do sistema central (sc, Figuras 8 e 9) percorrem vários internódios, ao longo do colmo. Em seu trajeto, eles se ramificam em certos nós e não se ramificam em outros. As ramificações são as seguintes:
a) Anastomoses entre feixes centrais (cc);
b) anastomoses entre feixes centrais e o sp (cp);
c) bifurcações acrópetas (ba);
d) bifucações basipetas (bb) ;
e) traços gemares centrais (tg);
f) traços foliares terminais $\left(t f_{1}, t f_{2}, t f_{3}\right)$;
g) traços foliares laterais (tl). 


\subsubsection{Curso descendente dos feixes centrais que emitem traços foliares terminais e suas conexões}

Na realidade, o curso descendente de um feixe que emite um traço foliar terminal, é o inverso do curso do seu desenvolvimento ontogênico. A descrição de um feixe, pelo seu curso descendente é, pois, apenas didática. Em consideração sobre o desenvolvimento de feixes, a partir dos traços gemares do tolete, é, muitas vezes, necessārio acompanhar - feixe no sentido ascendente.

Na Figura 8, encontram-se três traços folia-

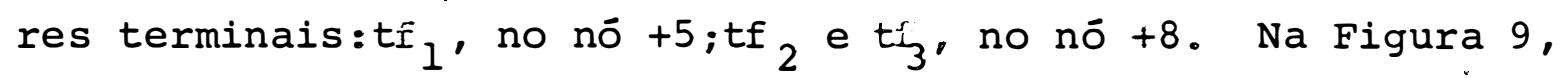
há dois traços foliares terminais: tf ${ }_{1}$, no nó +5 ; e tf́, no nó +6 .

\subsubsection{Traços foliares terminais do CV NA 56-79}

Na Figura 8, esses traços são três ttf $_{1}, t_{\dot{i}} 2$ e $\left.t f_{3}\right)$. o traço tf está no nó +5 . O feixe que lhe deu origem desce até o nó +9 , onde se funde com o sp, abrangendo 5 nós no seu percurso. Ontogeneticamente, esses feixes derivam de um cordão multifasciculádo do sp, no nó +9, logo abaixo da cị catriz foliar (cf). Esse feixe é um ramo de uma bifurcação acrópeta (ba), ocorrida no nó +7. o outro ramo dessa bifurcação continua seu percurso ascendente, anastomosando-se com outros feixes do sistema central. Antes da bifurcação, e ain 
da no nó +7 , ele se anastomosa com outro feixe central (cp) .

Na extremidade onde nasce o traço foliar, o feixe se conecta, por anastomose, com o sp e com o outro ramo da bifurcação ocorrida no nó +7 . No nó +6 , os dois ramos da bifurcação também se anastomosam.

o traço foliar terminal tf 2 está no nó +8 .

feixe que lhe deu origem desce até o nó +12 , onde se funde com o sp̣, abrangendo, também, 5 nós, no seu percurso. Ontogênica mente, a origem deste feixe é idêntica à do acima descrito. Ele se anastomosa com o sp no nó +10 , e com um feixe central, nos nós $+8,+10$ e +11 .

O traço tf 3 também está no nó +8 , porém no lado oposto ao do traçotf ${ }_{2}$. O feixe que lhe deu origem desce, per correndo todos os nós inferiores, para alēm do nó +19. No seu trajeto descendente, dentro da parte estudada do colmo, ele emitiu as seguintes ramificações:

a) na sua extremidade ramificada, o traço foliar terminal tf $f_{3}$ e suas anastomoses com o sp:

b) nos nós +11 , +15 e +19 , traços gemares centrais (tg);

c) anastomoses com o sp, nos nós +12 e +18;

d) anastomoses com outros feixes. centrais, nos nós +12 , +16 e +18 (cc);

e) no nó +18 , esse feixe produz uma bifurcação basipeta (bb), cujos ramos se anastomosam entre si 
no nó +19, e um deles, nesse mesmo nó, anastomosa-se com o sp (cp), do lado oposto do colmo, de onde se localiza o feixe.

Na Figura 3, da parte basal do colmo de uma planta nova, do cv. NA 56-79. nota-se, no nó +5, um traço foliar terminal $\left(t f_{l}\right)$. O feixe que lhe deu origem, emseu curso descendente, atravessa ono +6 , sem se ramificar e entra no rizoma, onde se anastomosa, no lo nó do mesmo, com outro feixe central, que nasce de uma bifurcação acrópeta (ba) de um feixe originado de um traço gemar periférico dotolete (tgpc) .

\subsubsection{Traços foliares terminais do CV. CB 4l-76}

Na Figura 9, esses traços sãodois $\left(t f_{1}\right.$ e $\left.t f_{2}\right)$. O traço tf até $\circ$ nó +8 , onde se funde com $\circ$ sp, abrangendo 4 nós no seu percurso. Ontogenicamente, a origem deste feixe é idêntica à dos já descritos. Na extremidade ondenasce o traço tf ${ }_{1}$, esse feixe produz duas ramificações deanastomoses, uma das quais se conecta com outro feixe central (cc). No nó +6 , ele se ramifi ca, emitindo traços gemares (tg), e anastomosando-se com aextremidade deoutro feixe, nabase do traço foliar tf 2 . No nó+7, ele seramifica emitindo também umtraço foliar lateral (tl).

o traço foliar terminal tf 2 está no nó +6. O feixe que the deu origem desce até o nō +16, onde se funde com o sp, abrangendo ll nós no seu percurso. ontogenicamente, esse feixe deriva de um cordão fibrovascular plu- . 
rifasciculado do sp. Na extremidade onde nasce o traço tf ${ }_{2}$ ' hã duas ramificações, uma das quais se conecta com $\circ$ feixe originante do traçotf. ${ }_{1}$ e a outra com outro feixe central. Nos nós $+8,+10$ e +12 , ele emite traços gemares centrais (tg) . No nó +9 , ele se anastomosa com $\circ$ sp $(\mathrm{cp})$.

Na Figura 5, da parte basal do caule de uma planta nova do cv. CB 41-76, notam-se, nos nós +5 e +6 , respectivamente, dois traços foliares terminais, $t f_{1}$ e $t f_{2}$. 0 feixe que originou o traçotf ${ }_{1}$, em seu curso descendente, passa pelos nós $+6,+7,+8$ e +9 , do colmo e, continuando o seu curso, através do rizoma, penetra no tolete, unindo-se a um cordão do $\operatorname{SP}\left(S_{1}\right)$. Ontogenicamente, esse feixe deriva de um traço gemar periférico do tolete (tgp).

Na sua extremidade $($ nó +5$)$, ele se anastomosa com dois feixes centrais $\left(f_{1}\right.$ e $\left.f_{2}\right)$. No nó +6 , ele se anas tomosa com os mesmos feixes. No nó +9 , anastomosa-se duas ve zes com $\circ$ feixe $f_{l}$. Na parte superior do rizoma, anastomosase, novamente, com $f_{1}$ e $f_{2}$. Na base do rizoma, ele se funde com $\circ$ feixe $f_{1}$. Neste ponto, verifica-se que, tanto $\circ$ feixe originante do traçotf $f_{1}$ como o feixe $f_{1}$ são ramos de uma bifur cação acrópeta (ba) do feixe central originado do traço gemar periférico (tgp) do tolete.

O feixe originante do traço tf ${ }_{2}(n o ́+6)$, em seu curso descendente, passa pelos nós $+7,+8$ e +9 ; do colmo e en tra no rizoma, onde se funde com $\circ$ sp̣. No nó +6 , além do trạ çotf ${ }_{2}$, ele emite duas ramificações, uma das quais de anastomo 
se com $\circ$ feixe $f_{1}$. No nó +7 , ele produz vārias ramificações e, no nó +9, ramifica-se novamente e anastomosa-se (cp) com o sp. Ontogenicamente, este feixe deriva de um cordão do sp do rizoma.

\subsubsection{Traços foliares laterais}

Foi encontrado um traço foliar lateral (tl) em cada um dos cultivares estudados. Na Figura 8 , esse traço en contra-se no nó +10 , e na Figura 9 ele se acha no nó +7 .

Na Figura 8, o traço tl é uma ramificação plagiótropa de um feixe central, localizada no nó +10. Esse feí xe se origina no sp, no nó +19 e percorre todo o colmo, até além do internódio +4 .

Na Figura 9, o traço tl é uma ramificação de um feixe central, originado no $\underline{\mathrm{sp}}$ do nó +8 . Nota-se que esse mesmo feixe produziu o traço foliar terminaltf ${ }_{1}$, no nó +5, já descrito (item 4.2.5.).

Na Figura 13, da parte basal do colmo de uma planta nova de NA 56-79, nota-se, no nó +2 , um traço foliar lateral (tl). O feixe que lhe deu origem é um dos ramos da bifurcação acrópeta (ba) do mesmo feixe que deu origem ao tra ço foliar terminal tf. Ontogenicamente, os dois traços t $_{1}$ e tI) derivam do mesmo feixe central, originado do traço gemar periférico (tgpc). 


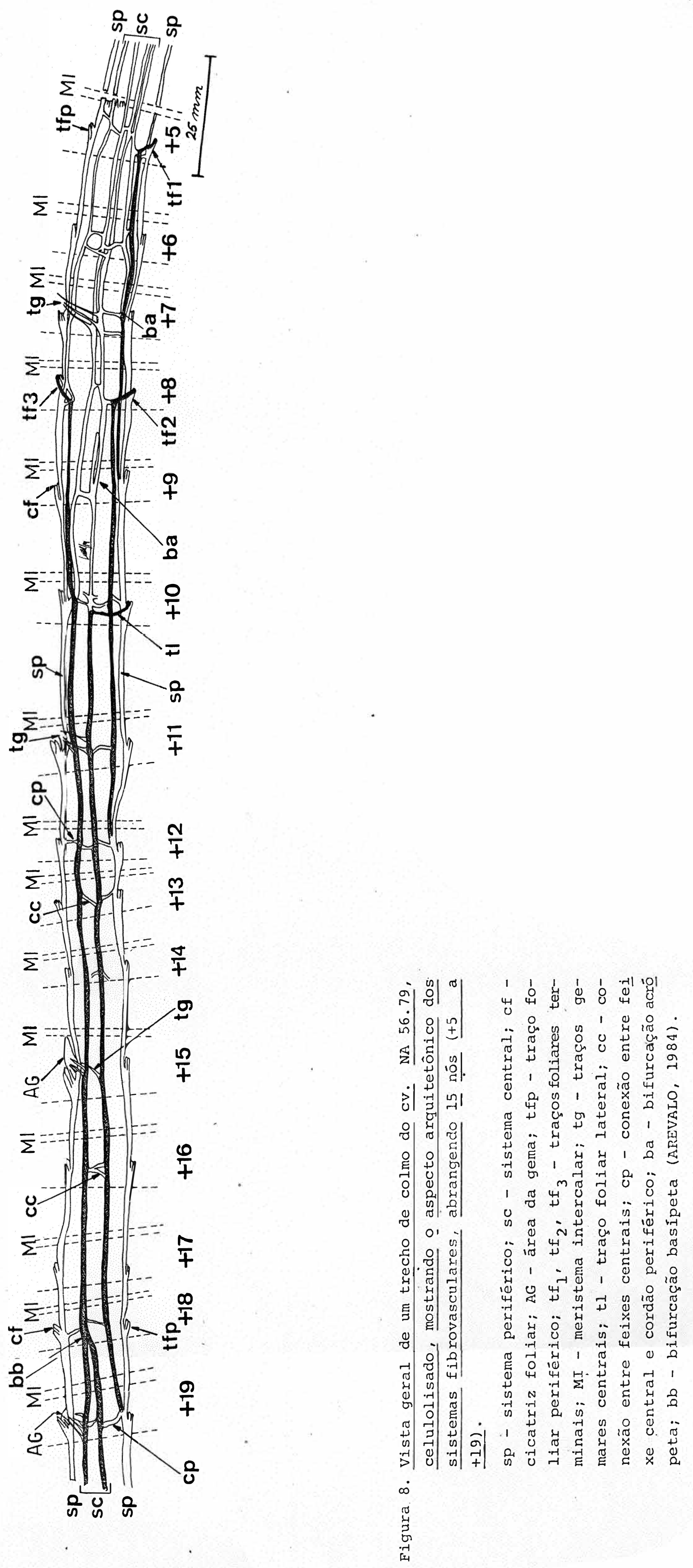




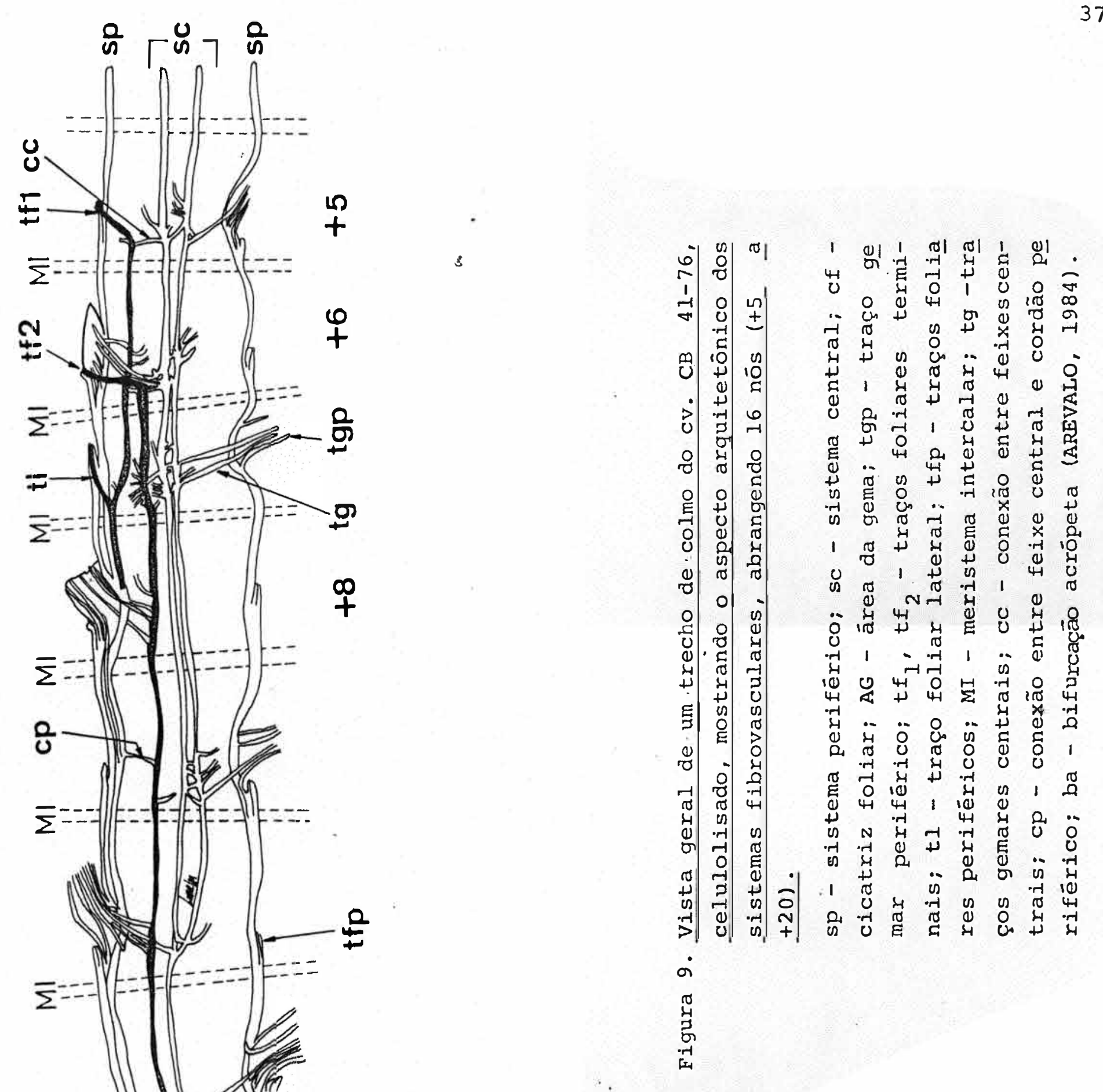




\subsubsection{Meristemas intercalares}

No cv. NA 56-79 (Figura 8), o meristema intercalar (MI) ainda está no início do seu amadurecimento, no internódio +4 , pois apenas alguns feixes centrais estão amadurecidos. Já, no internódio +5 , eles se mostram praticamente maduros.

No Cv. CB 41-76 (Figura 9), O MI já está camplę tamente maduro no internódio +4 .

4.3. Pesquisa III - Determinar a posição do nó em que oplẹ xo nodal já é funcional, em um cultivar precoce (NA 56-79) e em um tardio (CB 49-260).

Esta pesquisa mostrou, preliminarmente, que a arquitetura do sistema fibrovascular dos nós +9 até a do +5 não mostrava diferenças distintas. Estas diferenças começą ram a surgir a partir do nó +5 , até o nó +1 , nos cvs. NA 56-79 e CB $49-260$.

A descrição, acompanhando a evolução do desenvolvimento dos sistemas fibrovasculares, deve, pois, se iniciar no nó +1 , continuando para $\circ$ nó +5 , no qual a arquitetura ja está completa. 
4.3.1. Cv. CB 49-260 - Região do nó +1

A região do nó +1 , deste cultivar (Figura 10), está limitada pelos planos CD (superior) e GH (inferior). Ací ma do plano superior, localiza-se o MI, o qual foi totalmente celulolisado. Sua área está limitada pelas linhas $A B$ e $C D$.

A região do PN é limitada pelos planos EF e GH. Os feixes do SC são muito pouco ramificados e pouco conectados entre si. Nas regiões periféricas do SC, não há, pra ticamente, ramificações, a não ser o início dos primórdios de traços gemares.

Neste material, nota-se um traço foliar termi nal (tf), originado no ponto de conexão das extremidades de dois feixes axótropos.

O SP é formado pelos cordões fibrovasculares mul tifasciculados, que se ramificam axotropicamente. Dirigindo se para a área da gema ( $A G)$, notam-se três traços gemares periféricos (tgp), em início de formação.

Abaixo do plano inferior (GH) encontram-se 0 sistema fibrovascular do internódio inferior (II) e acima do plano superior ( $A B)$, o sistema fibrovascular do IS.

4.3.2. Cv. NA 56-79 - Região do nó +1

A regiạo do nó +1 , deste cultivar (Figura 11), 


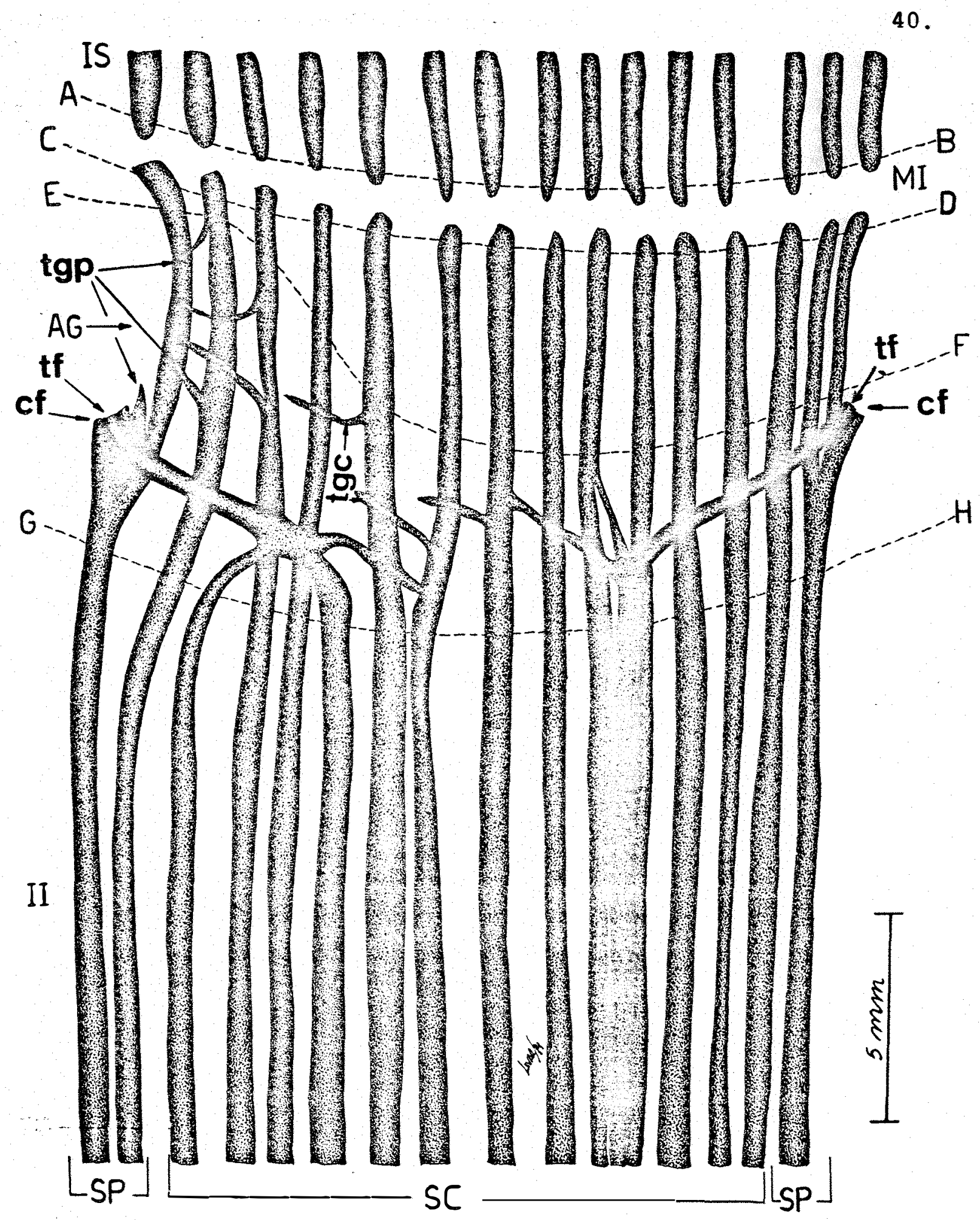

Figura 10. Aspecto da região do nó tl, do cv. CB 49-260. ABDC - meristema intercalar (MI); CDHG - região do nó; EFHG - região do plexo nodal; tf - traço foliar terminal; tgp - traço gemar periférico; tgctraços gemares centrais incipientes; SP - sistema periférico; SC - sistema central; AG - área da gema; IS - internódio superior; II - internódio infe rior; cf - cicatriz foliar (AREVALO, 1984). 
41.

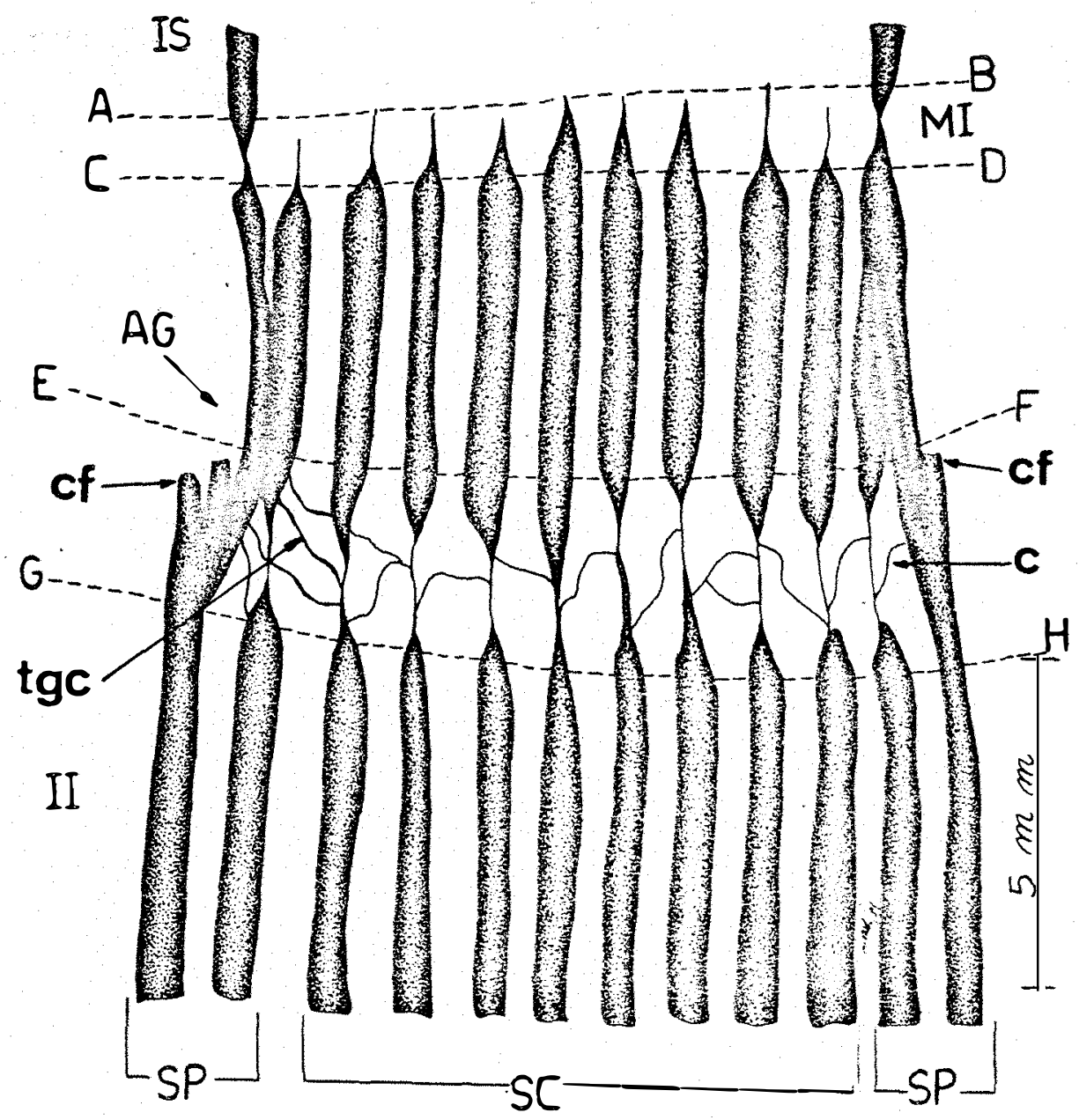

Figura 11. Aspecto da região do nó +1, do cv. NA 56-79.

ABDC - meristema intercalar(MI) CDHG - região do nó;

EFHG - região do plexo nodal incipiente; tgc - tra ços gemares centrais incipientes; SP - sistema periférico; SC - sistema central; c - conexão incipiente entre SC e SP; Cf - cicatriz foliar;AG -área da gema; IS - internódio superior; II - internódio inferior (AREVALO, 1984). 
está limitada pelos planos CD (superior) e GH (inferior). Aci ma do plano superior, localiza-se a área do MI, limitada pelos planos $A B$ e $C D$, onde se notam os inícios de lignificação dos feixes axótropos. Essa lignificação está mais avançada no SP, onde se encontram feixes $j a ́$ formados, atravessando a área do MI.

Ár região do PN é limitada pelos planos EF (su perior) e GH (inferior). Abaixo do plano inferior, encontrase o sistema fibrovascular do II, e acima do plano AB, localiza-se o internódio superior (IS), cujo SC foi totalmente ce lulolisado, permanecendo somente os feixes internos do SP, já lignificados.

Os feixes axótropos do SC na região do PN, mos tram-se extremamente delgados, indicando que somente os vasos estão lignificados, mas sua capa fibrosa ainda não. Os feixes plagiotrópos desta região são abundantes, delgados como os axótropos e uniformemente distribuídos em toda a área do SC. Notam-se conexões (c) entre o SC e O SP.

$\mathrm{Na}$ área central do PN, notam-se inícios de espessamentos esclerenquimatosos. Este fato indica desenvolvimento centrífugo do SC.

Comparando esta estrutura com a do Cv. CB 49260, observa-se que nesta ültima, o MI era totalmente celulósico. No cv. NA 56-79, porém, os vasos já estão parcialmente lignificados. Na região do $\mathrm{PN}$ do Cv $\mathrm{CB} 49-260$, as raras ramificações encontradas já estão completamente lignificadas, 
ao passo que no Cv. NA 56-79, as ramificações são abundantes, mas suas capas fibrosas não estão lignificadas. Este fa to indica que, no $C V$. $C B$ 49-260, os feixes plagiotropos vão se lignificando à medida em que se formam, enquanto que, no CV. NA 56-79, primeiro se formam todas as ramificações, e depois ocorre a lignificação de todas elas, simultaneamente. Ain da, na região do PN, observam-se os primórdios dos traços gemares centrais e periféricos, dirigindo-se para a área da gema (AG).

4.3.3. CV. CB 49-260 - Região do nô +2

A região do nó +2 deste cultivar (Figura 12) está limitada pelos planos CD (superior) e GH (inferior). Aci ma do plano superior, localiza-se o MI, em cuja região notase o início da lignificação dos feixes axótropos do SP e dos periféricos do SC, indicando lignificação centrípeta.

A região do PN é limitada pelos planos EF e GH. Nesta região, os feixes do SC são muito pouco ramifica dos e pouco conectados entre si, como ocorre com o nó +l. En tretanto, já são bastante conspícuos os poucos traços gemares centrais ( $\operatorname{tgc}$ ) e periféricos ( $\operatorname{gp} p$ ) que se desenvolvem em dire ção da ārea da gema (AG) .

Na região periférica do SC, notam-se raras ramificações, algumas delas de anastomoses com 0 SP.

Acima do plano superior do MI (plano $A B$ ), en- 
contra-se o sistema fibrovascular do Is e abaixo do plano inferior do PN (plano GH), o sistema fibrovascular do II.

$$
\text { 4.3.4. CV. NA 56-79 - Região do nó +2 }
$$

A região do nó +2 , deste cultivar (Figura 13), está limitada pelos planos AB (superior) e GH (inferior). Aci ma do plano superior da região nodal encontra-se a região do MI. Aćima da região MI e abaixo da região nodal, encontram se respectivamente os sistemas fibrovasculares dos internódios superior (IS) e inferior (II). A região do PN é limitada pelos planos EF e GH.

No MI já é evidente o amadurecimento centrífu go dos feixes fibrovasculares do SC. O SP ainda se mostra ima turo, pois foi totalmente celùlolisado juntamente com os feixes periféricos do SC.

A região do $\mathrm{PN}$ mostra um desenvolvimento mais amplo do que no $\mathrm{Cv}$. CB 49-260. Os feixes centrais já estão bem ramificados com suas ramificações atingindo a periferia do SC. Há conexões entre o SC e o SP e notam-se também bifur cações (b) nos feixes. Os traços foliares terminais (tf) são bem desenvolvidos. Os traços gemares centrais (tgc) e os periféricos (tgp) são bastante conspícuos.

4.3.5. Cv. CB 49-260 - Região do nó +3

A região do nó +3 , deste cultivar (Figura 14), 
45.

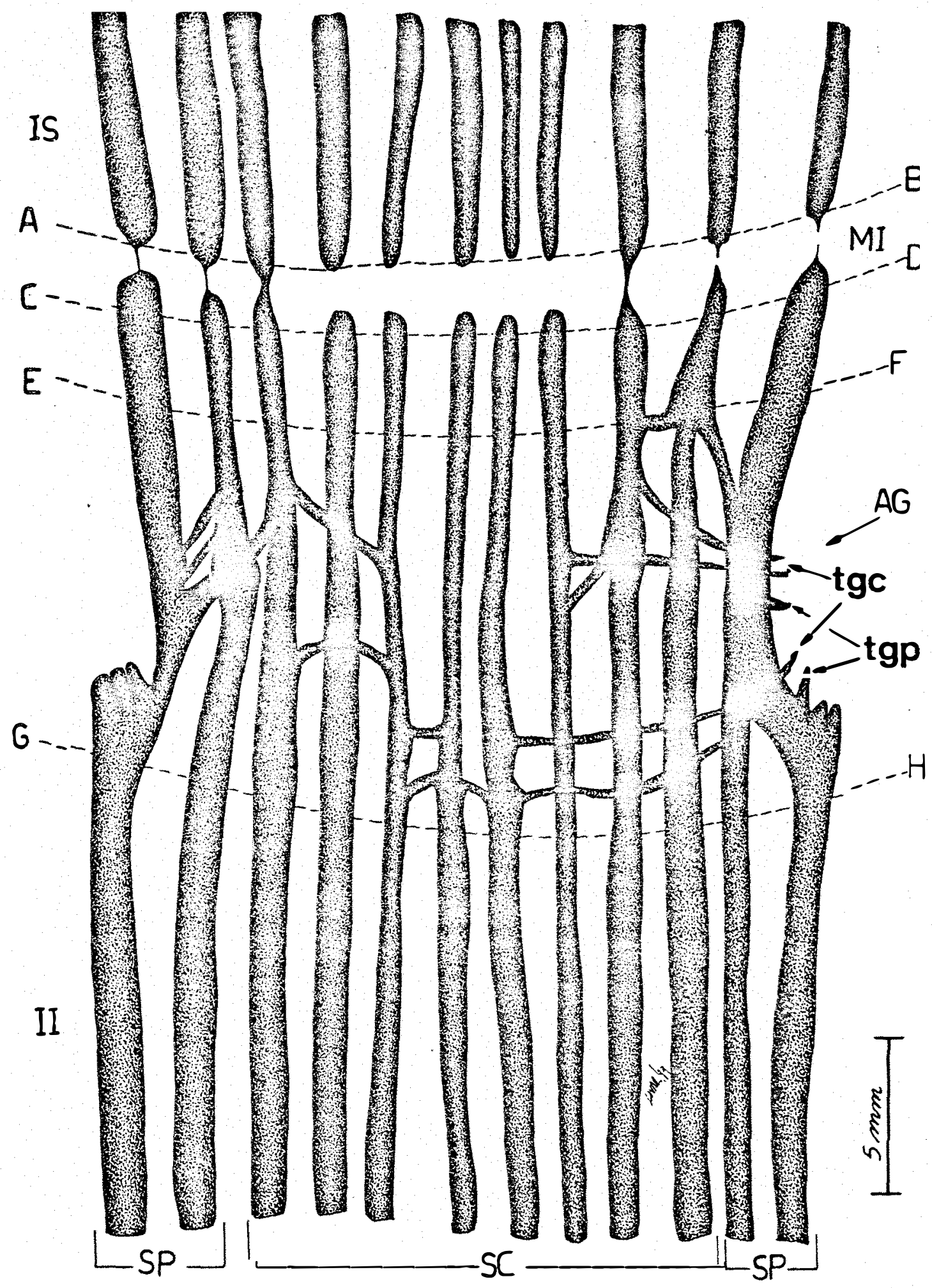

Figura 12. Aspecto da região do nó +2, do CV. CB 49-260. $A B D C$ - meristema intercalar (MI); CDHG - região do nó; EFHG - região do plexo nodal; tgc - traços gemares centrais; tgp - traços gemares perifểricos; AG - área da gema; SP - sistema periférico; SC-sis tema central; IS - internódio superior; II - inter nódio inferior (AREVALO, 1984). 
46.

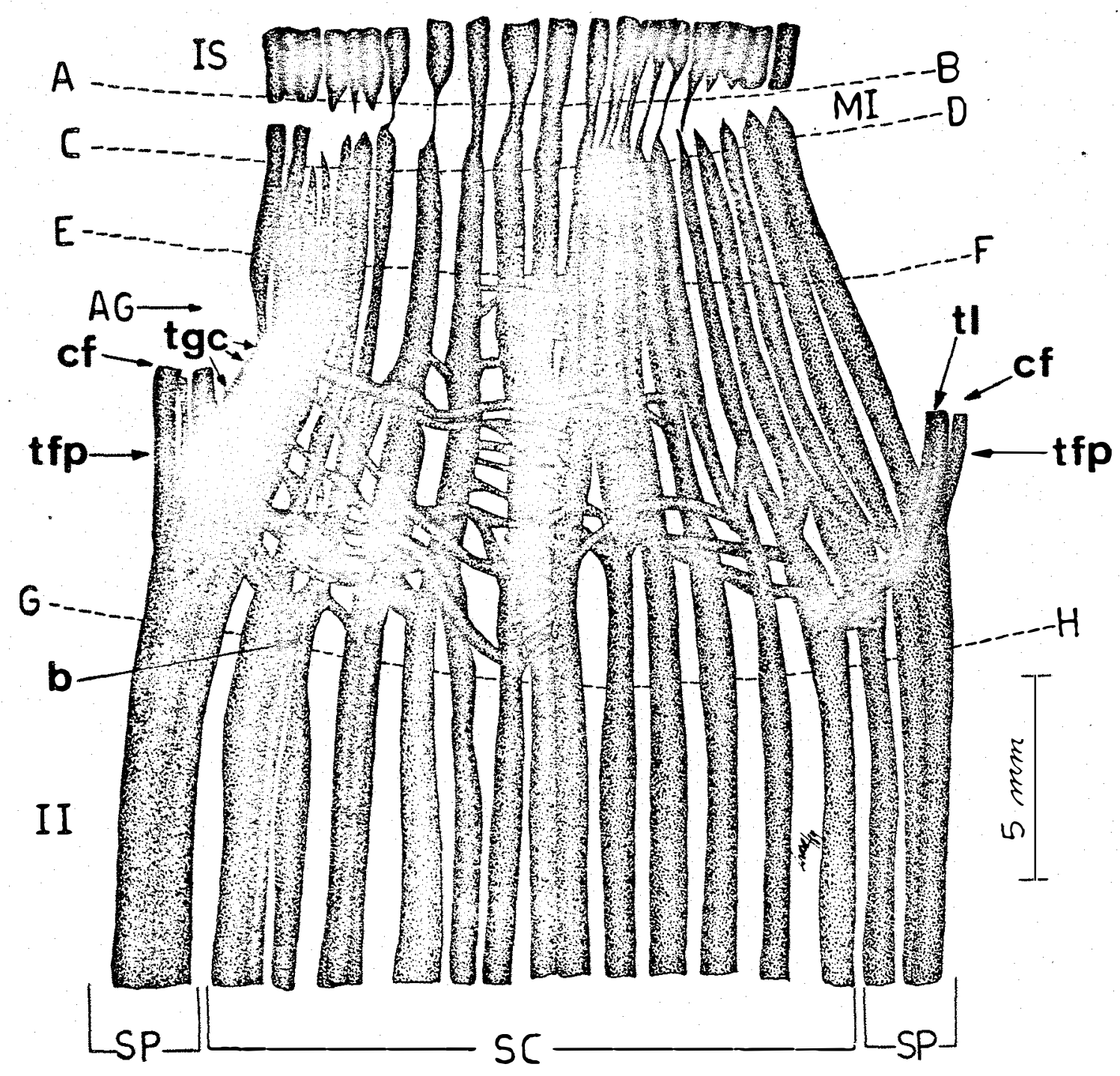

Figura 13. Aspecto da região do nó +2, do cv. NA 56-79.

$A B D C$ - meristema intercalar (MI); CDHG - região do nó; EFHG - região do plexo nodal; tfp - traço foliar periférico; tl - traço foliar lateral; tgc traços gemares centrais; AG - área da gema, cf - ci catriz foliar; b - bifurcação basipeta de um feixe central; SP - sistema periférico; SC - sistema cen tral; IS - internódio superior; II - internódio in ferior (AREVALO, 1984). 
está limitada pelos planos CD (superior) e GH (inferior). Aci ma do plano superior da região nodal encontra-se a região do MI. A região do PN é limitada pelos planos EF (superior) e GH (inferior). Acima do MI e abaixo da região do PN, encontram-se respectivamente, O IS e O II.

No MI, os cordões do SP, e alguns feixes periféricos do SC já estão lignificados. Na área do centro do SC, esses feixes ainda não estão lignificados, pois foram totalmente celulolisados. Este fato indica que a maturação dos feixes axótropos é centrípeta, iniciando-se pela periferia do SP (Figuras 12 e 14 ).

Os feixes axótropos do SC, na região do PN, já estão bem desenvolvidos, assim como os cordões do SP. As rami ficações plagiotropas encontram-se no centro do SC, como ocor re no nó +2 (Figura 12), porém, bem mais desenvolvidas e rami ficadas, conectando os feixes axotropos. Na área periférica do SC, raramente se encontram conexões plagiotrōpicas, a não ser algumas anastomoses com $\circ \mathrm{SP}$. Alguns feixes centrais bifurcam-se acrópeta e basípetamente. Nota-se também, a presença de um traço foliar terminal tff. Os traços gemares perí féricos ( $t g p$ ) e os centrais ( $\operatorname{tgc}$ ) são mais desenvolvidos que nos nós +1 (Figura 10) e +2 (Figura 12), penetrando conspi cuamente na área da gema (AG).

4.3.6. Cv. NA 56-79 - Região do nó +3

A região do nó +3 , deste cultivar (Figura 15), 
48.

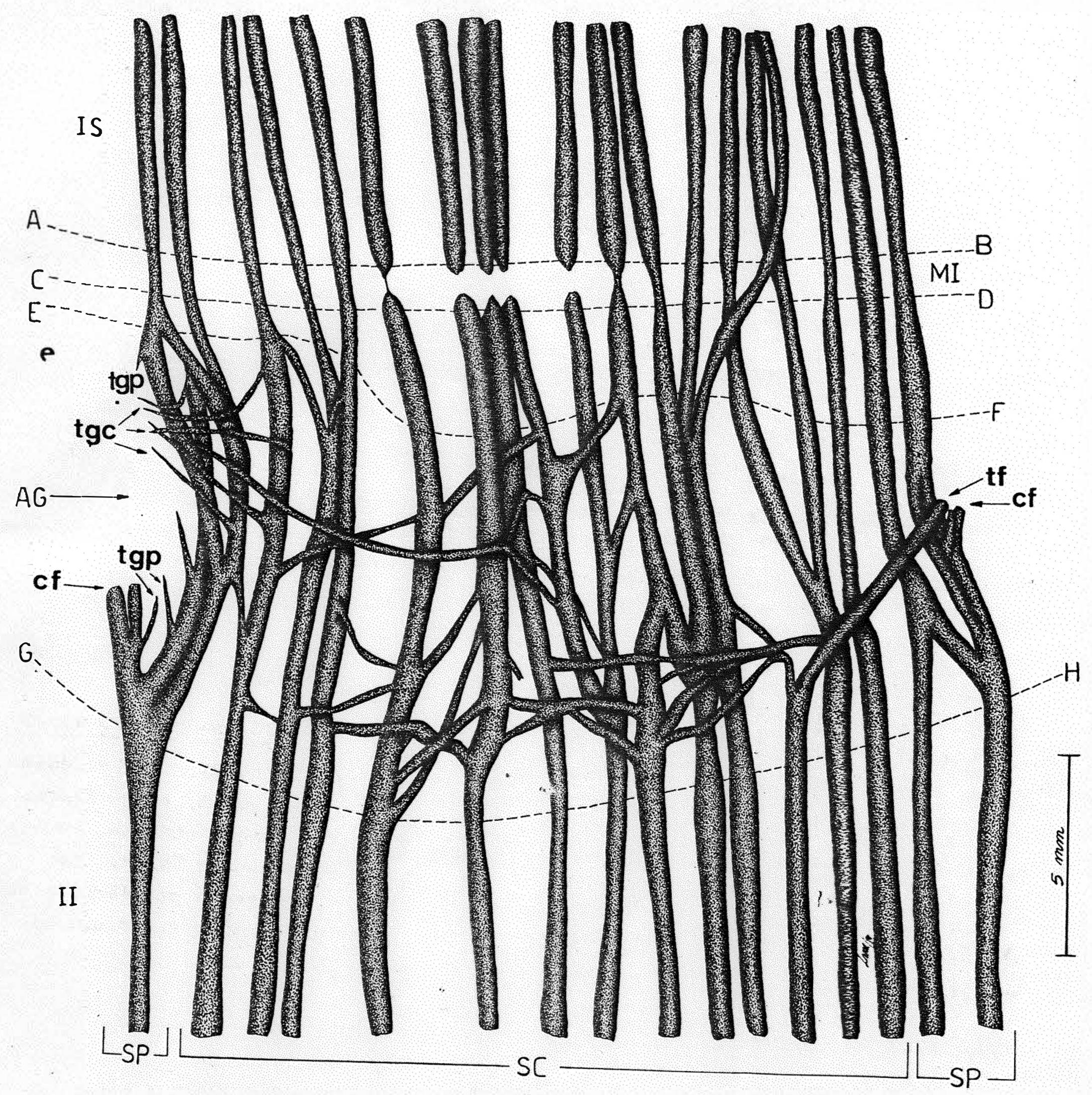

Figura 14. Aspecto da região do nó +3, do CV. CB 49-260.

ABDC - meristema intercalar (MI); CDHG - região do nó; EFHG - região do plexo nodal; tgp - traços gemares periféricos; tgc - traços gemares centrais; AG - área da gema; cf - cicatriz foliar; tf - traço foliar terminal; SP - sistema periférico; SC sistema central; IS - internódio superior; II - in ternódio inferior (AREVALO, 1984). 


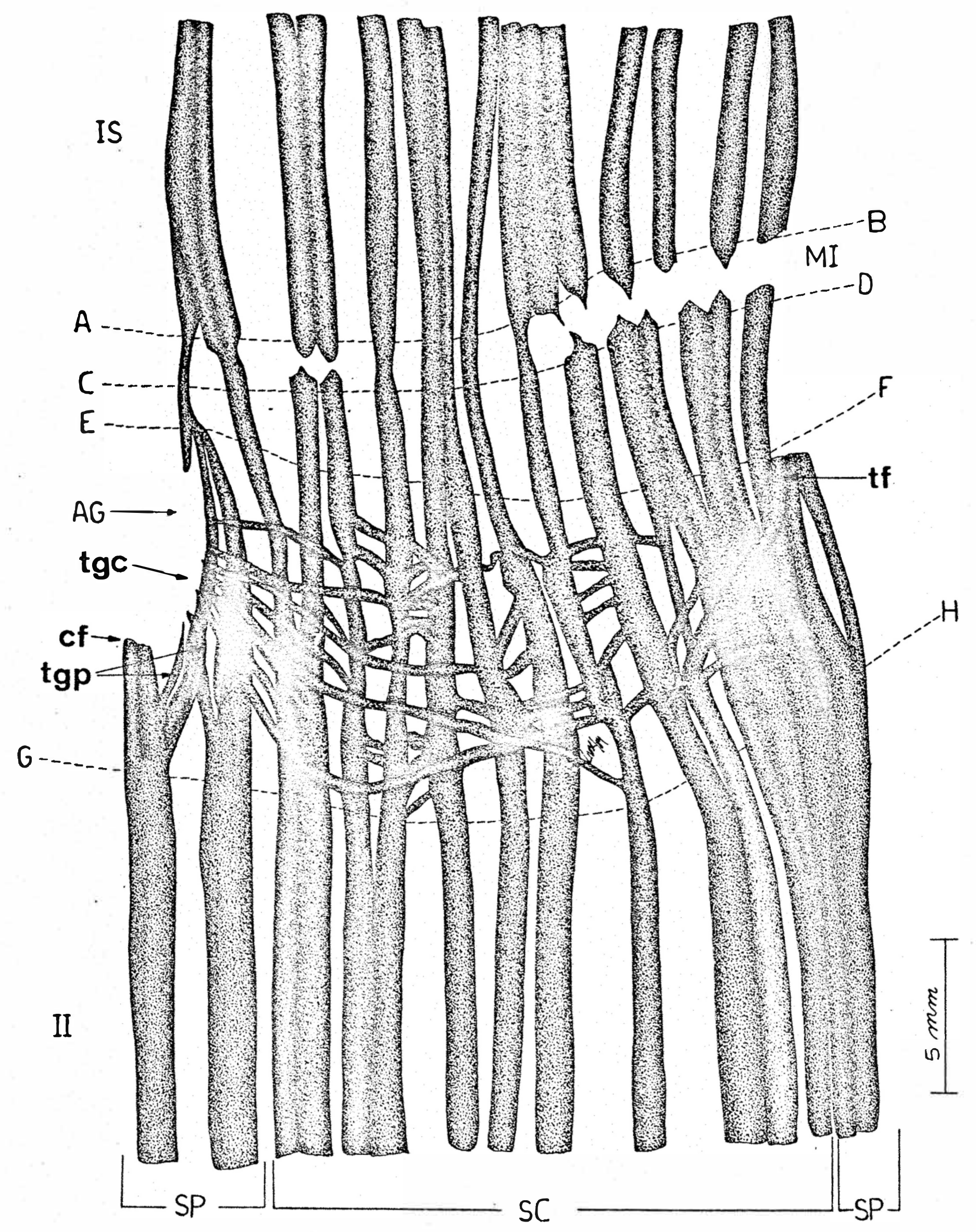

Figura 15. Aspecto da região do nó +3, do cv. NA 56-79. $A B D C$ - meristema intercalar (MI); CDHG - região do nó; EFHG - região do plexo nodal; tgp - traço gemar periférico; tgc - traços gemares centrais; tftraço foliar terminal; cf - cicatriz foliar; AG área da gema; SP - sistema periférico; SC - sistema central; IS - internódio superior; II - internó dio inferior (AREVALO, 1984). 
está limitada pelos planos CD (superior) e GH (inferior): Aci ma do plano superior da região nodal, encontra-se a região do MI, limitada pelos planos AB (superior) e CD (inferior). A re gião do PN é limitada pelos planos EF (superior) e GH (inferior). Acima do plano superior ( $A B)$ e abaixo do inferior (GH), encontram-se, respectivamente, O IS e O II.

No MI do lado da gema, nota-se que os cordões do SP já se encontram quase totalmente lignificados. Os fei xes do SC com lignificação mais desenvolvida situam-se na área central, sendo que, na periferia, ainda há feixes interrompidos por celulolisação. Nota-se, como no nó +2 (Figura 13i), uma tendência de amadurecimento centrífugo do SC. Na re gião do PN as ramificações plagiótropas são abundantes e mais numerosas do que no nó +3 (Figura I4) do Cv. CB 49-260. O SC e o SP neste nó já estão bastante anastomosados.

Observa-se que o sistema de traços gemares apa rentemente já está completo, distinguindo-se perfeitamente os traços gemares centrais ( $t g c)$ e os periféricos (tgp), penetran do na área da gema ( $\mathrm{AG}$ ). Do lado oposto ao da gema, observase um vigoroso traço foliar terminal (tf). Na base deste tra ço foliar, há ramificações de anastomose com feixes axótropos vizinhos.

$$
\text { 4.3.7. Cv. CB 49-260 - Região do nó +4 }
$$

A região do nó +4 , deste cultivar (Figura 16), está limitada pelos planos DC (superior) e GH (inferior). Aci 
ma do plano superior da região nodal, encontra-se a região do MI. O PN é limitado pelos planos EF (superior) e GH (inferior). Acima do MI e abaixo do PN, encontram-se, respectivamente, O IS e o II.

No MI, os cordões do SP e os periféricos do SC estão totalmente lignificados, evidenciando $\circ$ amadurecimento centrípeto do sistema fibrovascular, neste cultivar.

O PN está, neste nó, aparentemente, com desenvolvimento completo, similar ao do nó +3 . Os traços gemares centrais $(t g c)$ e periféricos $(t g p)$ são mais abundantes. Os traços foliares terminais ( $t f)$ e periféricos ( $t f p$ ) são conspícuos. Na base do traço foliar terminal, como ocorre nos anteriores, há ramificações terminais de anastomose com feixes vizinhos. Anastomoses entre $\circ$ SC e $\circ$ SP são raras.

4.3.8. Cv. NA 56-79 - Região do nó +4

A região do nó +4 , deste cultivar (Figura 17), está limitada pelos planos CD (superior) e GH (inferior). Aci ma do plano superior da região nodal, encontra-se a região do MI. A região do PN é limitada pelos planos EF (superior) e GH (inferior). Acima do MI e abaixo da região do PN, encon tram-se, respectivamente, O IS e O II.

No MI, os cordões externos do SP, do lado da gema, encontram-se quase totalmente lignificados, mas os subperiféricos ainda estão celulósicos. No lado oposto à gema 
- SP ainda nao está lignificado. NO SC é evidente o amadure cimento centrifugo dos feixes axótropos.

o PN, neste nó já tem seu desenvolvimento completo, com ramificações plagiotrópicas muito mais abundantes que no nó +4 do CV. CB 49-260 (Figura 16).

Os traços gemares periféricos e centrais e os traços foliares terminais e periféricos já se apresentam com as características da configuração de um nó maduro (AREVALO, 1983).

4.3.9. CV. CB 49-260 - Região do nó +5

A região do nó +5 , neste cultivar (Figura 18), está limitada pelos planos CD (superior) e GH (inferior). Aci ma do plano superior da região nodal, encontra-se a região do MI, limitada pelos planos AB (superior) e CD (inferior). A re gião do PN é limitada pelos planos EF (superior) e GH (inferior). Acima do MI e abaixo da região do $\mathrm{PN}$, encontram - se, respectivamente, O IS e O II.

No MI, O SP se encontra totalmente lignificado. No SC, verifica-se, ainda, a tendência do amadurecimento centrípeto.

O PN já se apresenta com seu desenvolvimento om pleto, mostrando abundantes traços gemares mais delgados do que os do nó correspondente de NA 56-79.

Na cicatriz foliar (cf) observa-se um traço foliar lateral (tl). 


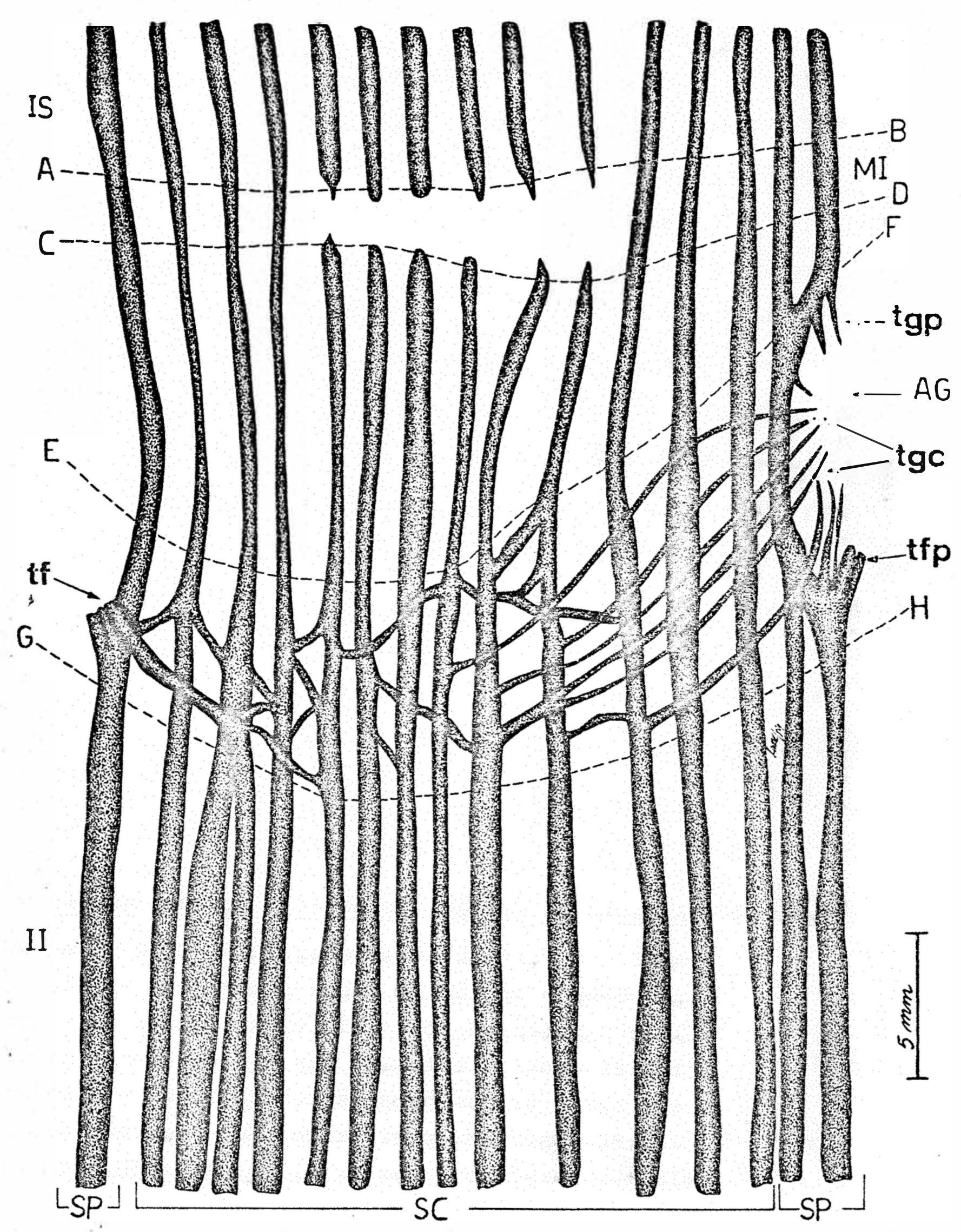

Figura 16. Aspecto da região do nó +4, do CV. CB 49-260.

$A B D C$ - meristema intercalar (MI); CDHG - região do nó; EFHG - região do plexo nodal; tgp - traços gemares periféricos; tgc - traços gemares centrais; tfp - traços foliares periféricos; tf - traços foliares terminais; AG - ārea da gema; SP - sistema periférico; SC - sistema central; IS - internódio superior; II - internódio inferior (AREVALO, 1984). 
54.

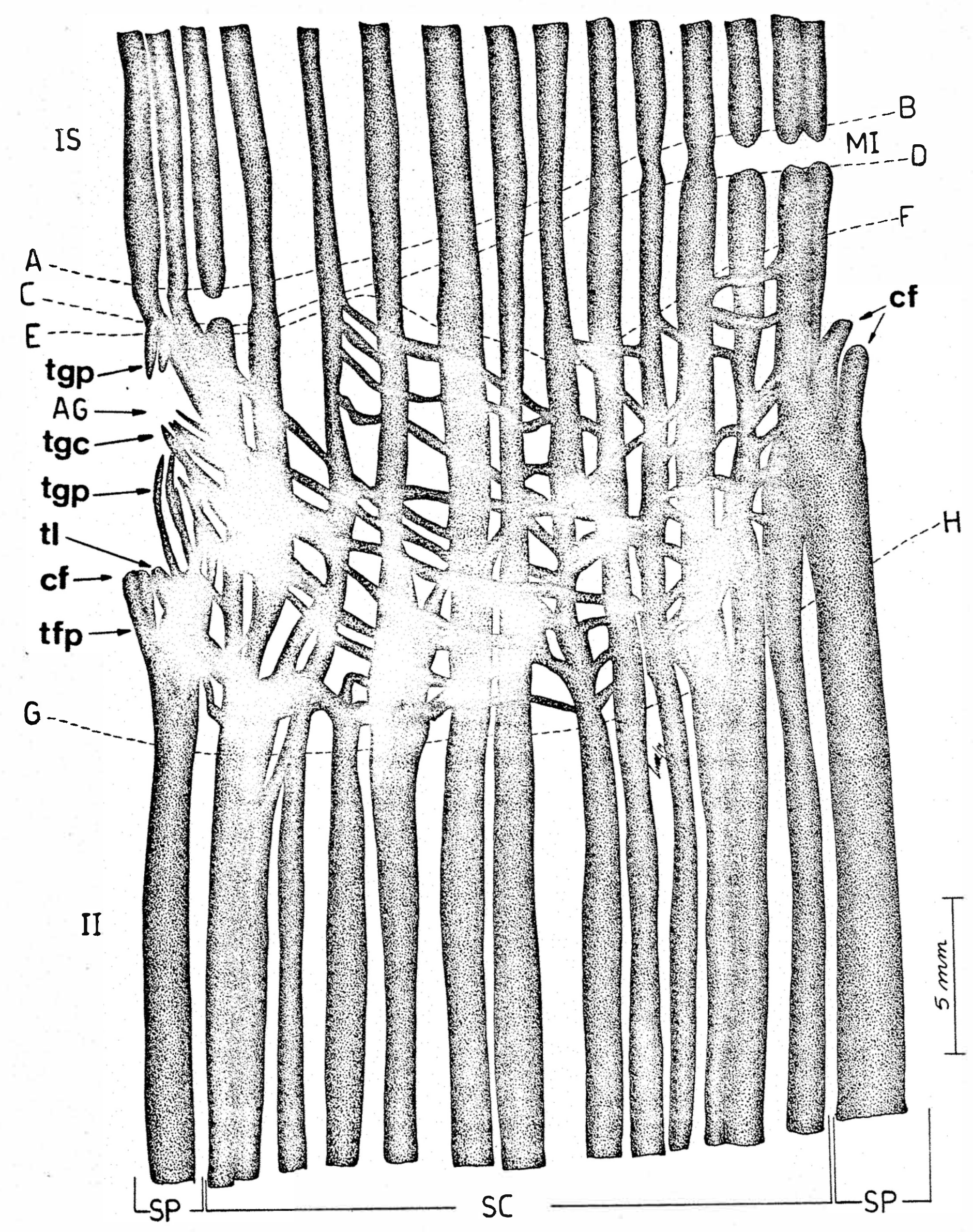

Figura 17. Aspecto da região do nó +4, do cv. NA 56-79.

ABDC - meristema intercalar (MI); CDHG - região do nó; EFHG - região do plexo nodal; tfp - traço foliar perifèrrico; cf'- cicatriz foliar; tl - traço foliar central lateral; tgp - traço gemar perifēri co; tgc - traços gemares centrais; AG - área da ge . ma; SP - sistema periférico; SC - sistema centrai; IS - internódio superior; II - internódio inferior (AREVALQ； 1984). 


\subsubsection{0. cv. NA 56-79 - Região do nó +5}

A região do nó +5 , deste cultivar (Figura 19), estå limitada pelos planos CD (superior) e GH (inferior). Aci ma do plano superior da região nodal, encontra-se a região do MI. Esta região é limitada pelos planos $A B$ e $C D$. A região do PN é limitada pelos planos EF (superior) e GH (inferior). Acima do MI e abaixo da região do PN encontram-se, respectiva mente, o IS e o II.

No MI, se observa, como nos nós mais novos des te cultivar, a lignificação centrífuga dos sistemas fibrovasculares.

O PN apresenta o mesmo grau de desenvolvimento do nó +4 deste cultivar. Em comparação com o cv. CB 49-260 (Figura 18), O PN de NA 56-79 é bem mais complexo, mais desen volvido e mais lignificado.

4.4. Pesquisa IV - Determinar, pela germinação, o nó mais jovem, cujo plexo nodal já seja funcional em um cultivar precoce (NA 56-79) e em um tardio (CB 49$260)$.

Em um experimento em blocos inteiramente casua lizados, com 10 tratamentos (gemas) e 8 repetições (vide item 3.7.) foram obtidos os resultados indicados nas Tabelas 1 e 2 . 


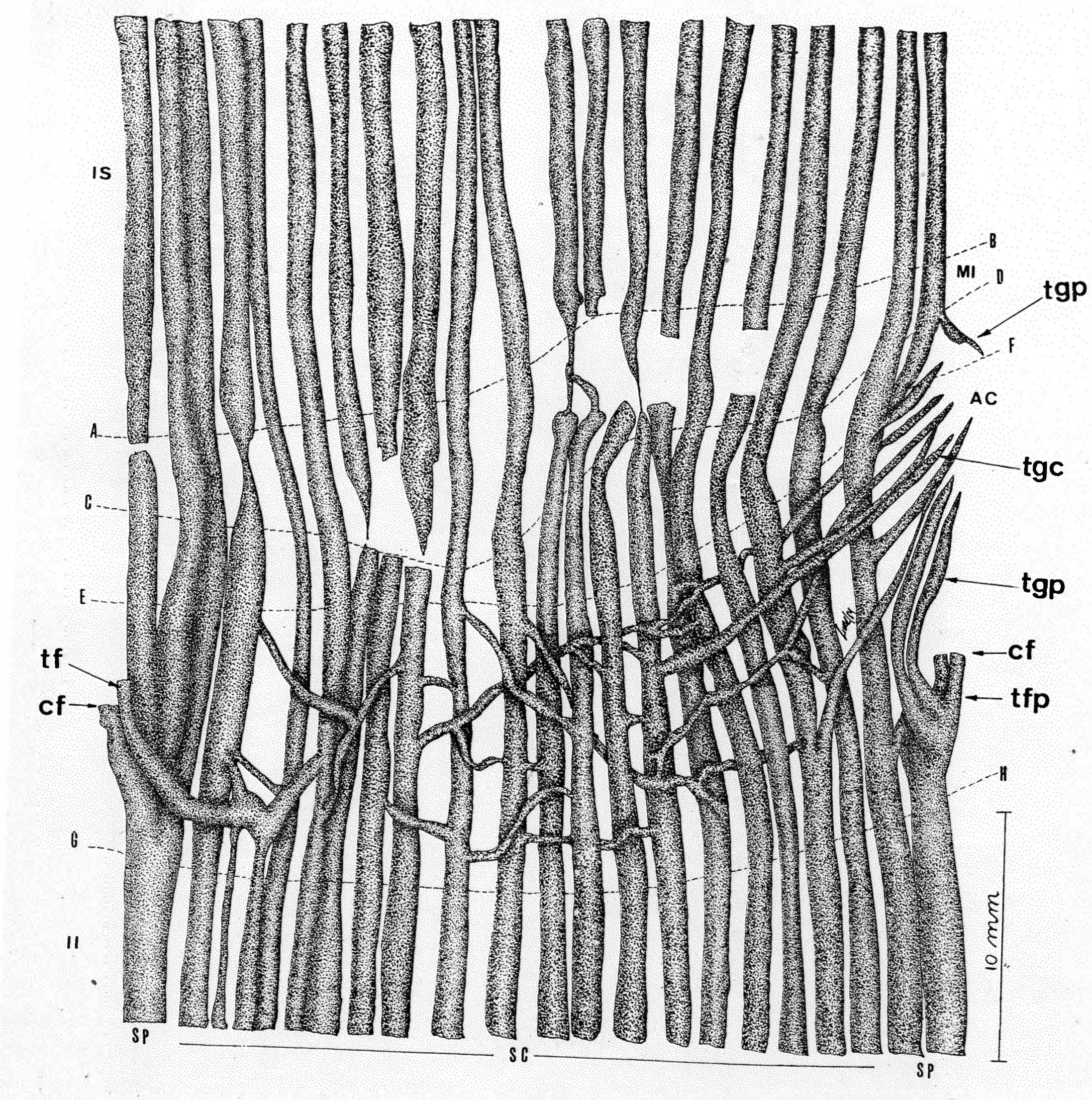

Figura 18. Aspecto da região do nó +5, do cv. CB 49-260.

ABDC - meristema intercalar (MI); CDHG - região do nō; EFHG - região do plexo nodal; tfp - traço foliar periférico; tgp - traços gemares periféricos; tgc - traços gemares centrais; cf - cicatriz foliar; tf ... traço foliar terminal; AG - área da gema; SP - sistema perifërico; SC - sistema central; IS - internódio superior; II - internódio inferior (AREVALO, 1984). 
57.

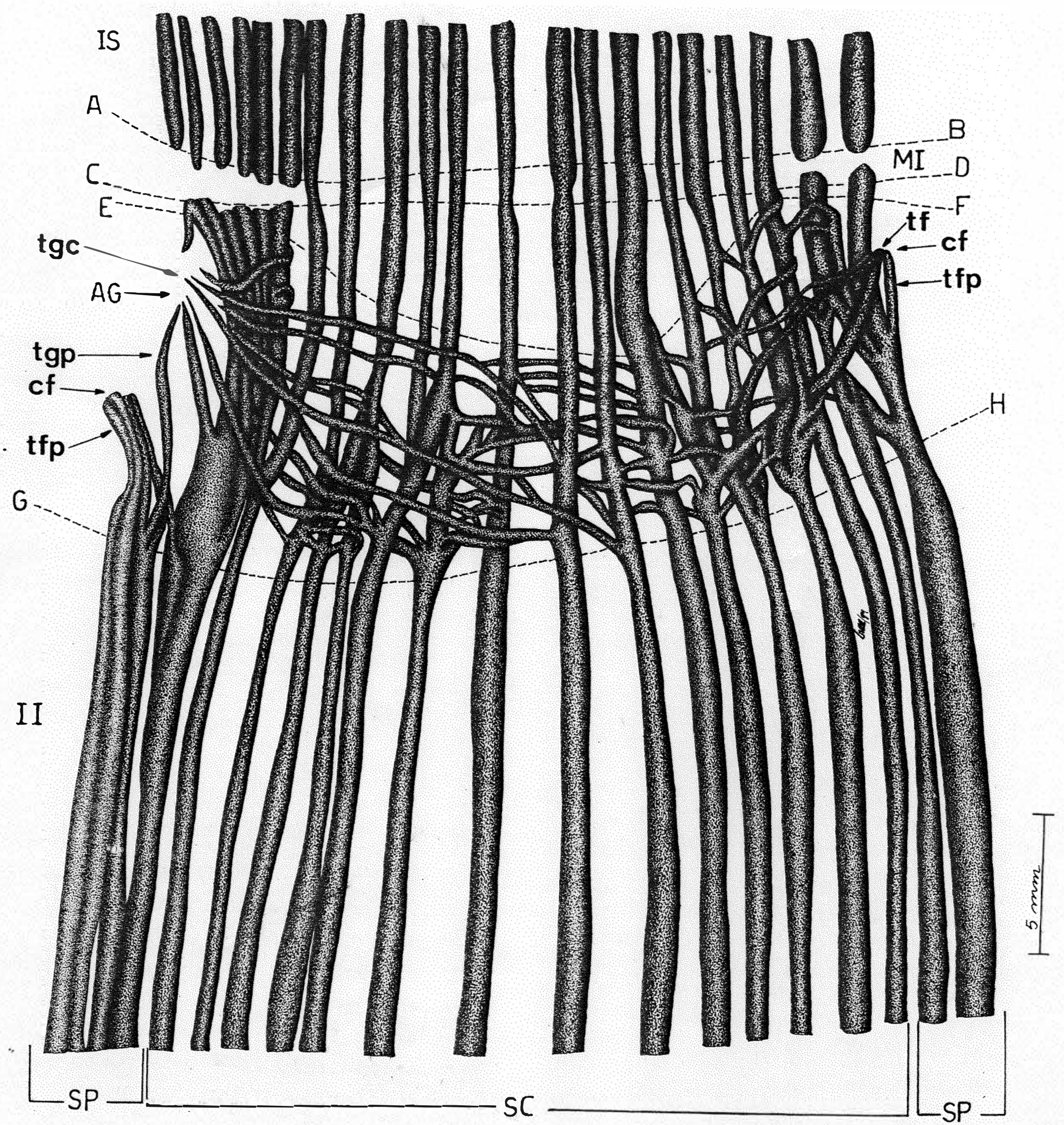

Figurá 19. Aspecto da região do nó +5, do cv. NA 56-79.

$A B D C$ - meristema intercalar (MI); CDHG - região do nó; EFHG - região do plexo nodal; tl - convergência de três traços foliares centrais laterais; tfptraço foliar periférico; tgp - traço gemar periférico; tgc - traços gemares centrais; AG - área da gema; cf - cicatriz foliar; SP - sistema perifériCo; SC - sistema central; IS - internōdio superior; II - internódio inferior (AREVALO, 1984). 
Tabela 1. Plântulas emergidas 30 dias após o plantio. Cv. NA 56-79.

\begin{tabular}{lccccccccc}
\hline & \multicolumn{10}{c}{ Repetições } \\
\cline { 2 - 8 } & I & II & III & IV & V & VI & VII & VIII \\
\hline+9 & + & + & + & + & + & + & + & + \\
+8 & + & + & + & + & + & + & + & + \\
+7 & + & + & + & + & + & + & + & + \\
+6 & + & + & + & + & + & + & + & + \\
+5 & + & + & + & + & + & - & + & + \\
+4 & + & + & + & + & + & + & + & + \\
+3 & + & + & + & + & + & + & + & + \\
+2 & + & - & - & - & - & + & - & - \\
+1 & - & - & - & - & - & - & - & - \\
0 & - & - & - & - & - & - & - & - \\
\hline
\end{tabular}

(+) plântulas emergidas

(-) plântulas não emergidas

Os dados das tabelas 1 e 2 mostram que no cultivar tardio, o PN é funcional a partir do nó +2 , ao passo que, no cultivar precoce, somente a partir do nó +3 se compro va a funcionalidade do $\mathrm{PN}$.

A vista da clareza dos dados, não foi necessária análise estatistica. 
Tabela 2. Plântulas emergidas 30 dias após 0 plantio, cv. CB $49-260$.

\begin{tabular}{|c|c|c|c|c|c|c|c|c|}
\hline \multirow{2}{*}{ Trat. } & \multicolumn{8}{|c|}{ Repetições } \\
\hline & $I$ & II & III & IV & $\mathrm{V}$ & VI & VII & VIII \\
\hline+9 & + & + & + & + & + & + & + & + \\
\hline+8 & + & + & - & + & + & + & - & + \\
\hline+7 & + & + & + & + & + & + & + & + \\
\hline+6 & + & + & + & + & + & + & + & + \\
\hline+5 & + & + & + & + & + & + & + & + \\
\hline+4 & + & + & + & + & + & + & - & + \\
\hline+3 & + & + & + & + & + & + & + & + \\
\hline+2 & + & + & + & + & + & + & + & + \\
\hline+1 & - & - & $=$ & + & - & - & - & - \\
\hline 0 & - & - & - & - & - & - & - & - \\
\hline
\end{tabular}

(+) plântulas emergidas

(-) plântulas não emergidas. 
60 .

\section{DISCUSSÃO}

As pesquisas relatadas neste trabalho tiveram por objetivos determinar a arquitetura dos sistemas fibrovasculares da cana-de-açūcar, desde sua origem no tolete, seu relacionamento com as raízes adventícias, as gemas, os ramos e as folhas, bem como o trajeto dos feixes e suas ramificações ao longo do rizoma e do colmo e determinar a posição do nó em que o plexo nodal (PN) já é funcional, em um cultivar precoce (NA 56-79) e em um tardio (CB 49-260).

5.1. Discussão da literatura

ARTSCHWAGER (1925) jā havia identificado os sistemas fibrovasculares da cana-de-açūcar - o sistema periférico (SP) e o sistema central (SC). Entretanto, na região nodal, ele não conseguiu esclarecer a correta configuração dos dois sistemas nem o seu relacionamento mūtuo. 
Outros autores (ТАNIMOTO, 1964, em Saccharum sp.: SHARMAN, 1942; e KUMAZAWA, 1961, ambos em Zea mays), estudaram a arquitetura nodal, sem conseguir esclarecê-la, por deficiência do método clássico de estudos anatômicos. AREVALO (op. cit.) usando o método do microbiocelulolítico, conseguiu esclarecer definitivamente a arquitetura da rede fibrovascular nodal da cana-de-açúcar. Nessas condições, os estudos das regiões nodais relatadas neste trabalho tiveram um ob jetivo essencialmente ontogênico no contexto das pesquisas realizadas.

Os diversos autores citados, tentaram esclarecer o trajeto dos feixes fibrovasculares ao longo do. colmo e seu relacionamento com folhas, gemas e raizes.

Esses autores consideravam os feixes centrais como "traços foliares" que saiam da bainha para a região nodal e desciam, atravessando vários nós, no sentido basipeto. AREVALO (op. Git.) mostrou que esses feixes não são traços. foliares, mas feixes fibrovasculares do SC.

Os esforços dos autores citados, em determinar com segurança o trajeto dos feixes axótropos ao longo do colmo foram praticamente infrutiferos, como confessa ARTSCHWA GER (op. cit.), embora ele tenha conseguido acompanhar um fei xe central através de 8 internódios, não tendo, entretanto, $\infty$ n seguido encontrar sua conexão final (ver item 2).

SHARMAN (op. cit.) estudou Zea mays. Ele tentou acompanhar o curso de feixes centrais através do colmo con 
seguindo encontrar conexões de feixes centrais com o SP, que ele refere como "cordões laterais" (ver item'2).

KUMAZAWA (op.cit.) estudou, também em Zea mays, os feixes axótropos, por ele denominados "cordões de traços foliares", que ele classificou em 3 tipos:

18 tipo - representado pelos "cordões de traços foliares", que seguem mais ou menos o curso interno e, à altura de alguns nós mais abaixo, se encaminham para a periferia e juntam-se com o "sistema interno".

Estes "cordões de traços foliares" são justamente os feixes do sistema central, estudados na Pesquisa II, Itens 4.2.4. e 4.2.5., que terminam em traços foliares. O "sis. tema interno" citado por KUMAZAWA é o SP referido no item 4.2.1. deste trabalho. Por conseguinte, as pesquisas relatadas nos itens 4.2.4. e 4.2.5. em cana-de-açúcar confirmam as conclusões de KUMAZAWA, para Zea mays.

20 tipo - representado pelos "cordões de tra ços foliares" que chegam diretamente à posição dos feixes mais periféricos e se unem, mais cedo ou mais tarde com eles.

Estes "cordões" correspondem exatamente aos traços foliares periféricos, visíveis nas cicatrizes foliares (Pesquisa II, item 4.2.1.).

39 tipo - representado pelos "cordões" muito pequenos e que logo morrem dentro do cortex, ao nível do nó ou próximo a ele.

Este 3o. tipo de traço foliar, na realidade 
não existe. KUMAZAWA não conseguiu interpretar os pequenos traços foliares periféricos, que são ramificações dos cordões do SP à altura da cicatriz foliar, por não ter encontrado as conexões desses feixes com o SP. Este"38 tipo" de KUMAZAWA, é, na realidade, um traço foliar do "28 tipo" da sua própria classificação. A Figura 20 mostra o esquema da interpretação da arquitetura dos sistemas fibrovasculares por KUMAZAWA.

Em relação ao trajeto dos feixes, descrito por KUMAZAWA, em Zea mays (Figura 20), cabem as seguintes observaçōes :

a) em cana-de-açūcar (Pesquisa II), foram encontrados feixes centrais cujos trajetos coincidem com os de KUMAZAWA, os quais, descendo vārios internódios, se fundem com o sp, do mesmo lado do traço foliar (Figura $20, \mathrm{M}_{1}, \mathrm{M}_{2}$ ' $\left.\mathrm{M}_{3}, \mathrm{M}_{7}, \mathrm{M}_{10}, \mathrm{~m}_{4}, \mathrm{~m}_{5}, \mathrm{~m}_{6}, \mathrm{~m}_{7}, \mathrm{~m}_{9}, \mathrm{~m}_{10}\right)$;

b) não foram encontrados feixes que emitem tra ços terminais de um lado e se fundem com o sp no lado oposto, após descerem vários internódios $\left(M_{6}, M_{8}, m_{8}\right)$.

Uma observação interessante do esquema de KUMAZAWA (Figura 20) é a de que todo o sistema fibrovascular central origina-se do sistema periférico, a partir do coleoptilo. Na cana-de-açūcar (itens 4.1. e 4.2.) também o sistema central, pelo menos em parte, origina-se do SP do tolete ou do colmo primário (sp). 
64.

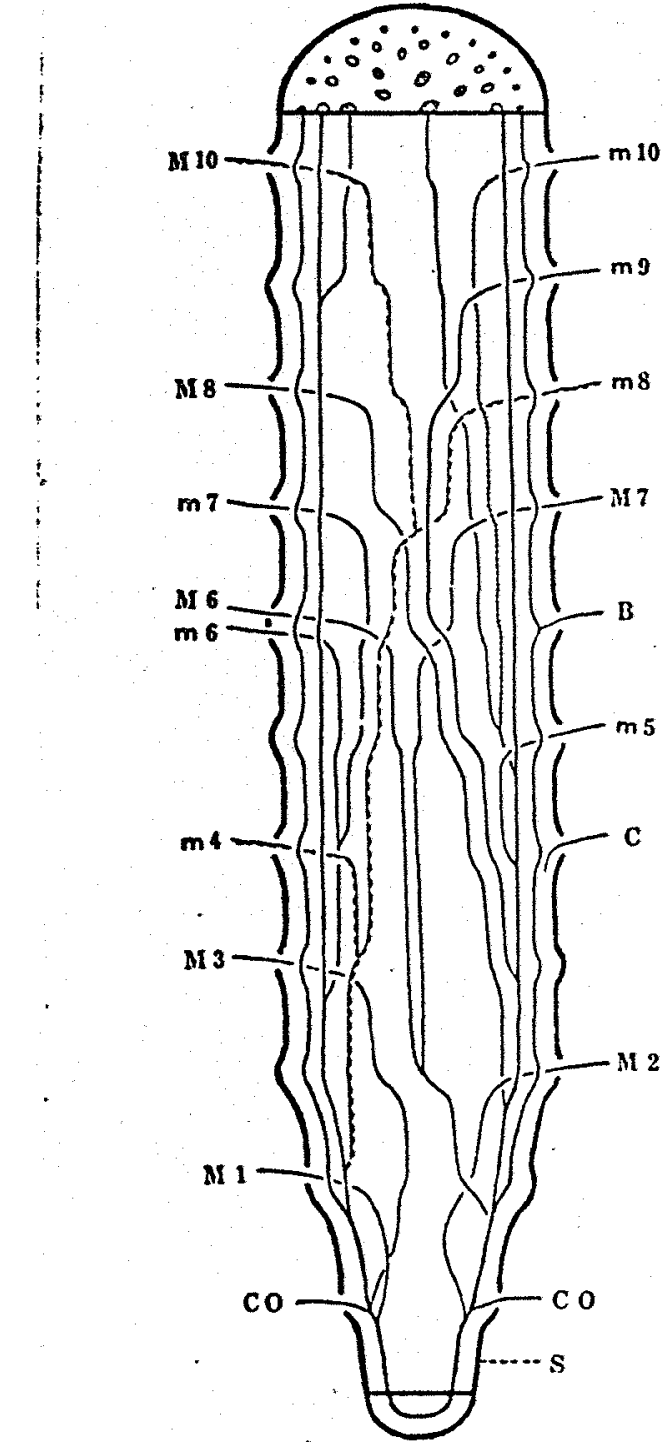

Figura 20. Diagrama mostrando o aspecto dual do sistema vascular e o curso longitudinal de traços foliares em. um caule vegetativo com 10 nós. (Em Zea mays) $\mathrm{M}_{1}-\mathrm{M}_{10}$, cordões de traço foliar das nervuras principais da lạ à loạ folha; $\mathrm{m}_{4} \mathrm{~m}_{10}$, cordões de traço foliar das nervuras laterais da 4ạ à lọ̣ foIha: CO - cordão de traço do coleóptilo; B e C cordões de traços foliares do 29 e do 39 tipo, res pectivamente; $S$ - mesocótilo (KUMAZAWA, 1940b, cf. KUMAZAWA, 1961). 
A bibliografia referenteàs pesquisas sobre o meristema intercalar é escassa e rara. Sobre a cana-de- açúcar, somente se conhecem os estudos de ARTSCHWAGER (ㅇp. cit.).

Esse autor demonstrou que, no meristema intercalar, os feixes são muito pouco lignificados e a sua resistência é garantida por uma enorme bainha de colênquima. Essa bainha, nas fases mais avançadas do amadurecimento, esclerificam-se.

E interessante anotar aqui, uma impropriedade de expressão de ARTSCHWAGER: "The chief divergence from the normal structure consists in a transformation of the sclerenchyma bundle caps into collenchyma and in a general reduction of the lignified cells of the vascular part of the bundle".

Naturalmente, o esclerenquima, tecido morto, não pode se transformar em colênquima, tecido vivo.

Tal "ressurreição" só pode ser devida a uma lapso de distração do eminente botânico. DILLEWIJN (1952), já corrigiu esse texto: "... and the sclerenchyma is here replaced by collenchyma".

ARTSCHWAGER se refere "a um grande colênquima que rodeia pequenos núcleos vasculares", o que, mais tarde, após esclerificação, explica a aglomeração das bainhas esclerenquimáticas, formando uma casca fibrosa e resistente - a casca da cana.

Os "pequenos núcleos vasculares" do meristema intercalar, referidos por ARTSCHWAGER, nesse trabalho, podem 
ser mais bem explicados, quando se estudam sucessivos nós pelos métodos microbiocelulolíticos, porque por este método pode-se acompanhar a lignificação progressiva no desenvolvimento ontogênico dos feixes no meristema intercalar.

Assim, no item 4.3.1. deste trabalho, todo o MI está totalmente celulolisado, o que indica que ainda não havia se iniciado a lignificação dos vasos. Este é o nó tl do cv. CB 49-260. No nó +2 (item 4.3.3.), já se notam os inícios da lignificação dos feixes do SP e dos periféricos do SC. No outro cultivar (NA 56-79), já se nota, no nó +1, o início da lignificação dos feixes na região do MI.

Por outro lado, um simples corte transversal no MI não é suficiente para revelar o real estado de maturidade dos feixes. Isso porque a lignificação dos vasos e a consequente esclerificação da bainha colenquimatosa do feixe se efetua progressiva e convergentemente, a partir das extremidades dos feixes maduros do nó e dos correspondentes, também maduros, do internódio superior, situados, respectivamente, a baixo e acima do MI.

O MI é um disco de aproximadamente $2 \mathrm{~mm}$ de espessura, cuja região mediana éa de divisão celular. Os feixes fibrovasculares do colmo, nessa região,são colenquimáticos, em internódios jovens. Isto equivale a dizer que um feixe fibro vascular que atravessa o MI tem, nessa região, em lugar da bai nha esclerenquimática, uma bainha de colênquima.

Pelo método microbiocelulolítico, é possível de- 
terminar, emnos sucessivos, os distintos estágios deamadurecimento dosfeixes. De um modo geral podem-se distinguir, pelo exame do MI, estágios deamadurecimento dos feixes (Figura 21): Estágio I - Vasos não lignificados, bainha totalmente colenquimatica. Sofre celulolisação completa (Fig. 21, I: Fig. 10).

Estágio II - Vasos com início de lignificação e início de esclerificação da bainha colenquimática, convergin do progressivamente, para a região de divisão celular. Sofrem celulolisação do colênquima, evidenciando as partes recém-esclerificadas, que são cônicas com os vértices convergentes pạ ra a região de divisão celular (Fig. 2l, II, Fig. 1l).

Estágio III - Vasos totalmente lignificados. Os vértices dos cones de esclerificação se tocam na região de divisão celular, formando um corpo de ampulheta. o restan te colenquima celulolisa-se (Fig. 21, III; Fig. 13).

Estágio IV - Vasos de feixes totalmente lignificados. Esclerificação da bainha completada. A celulolisação não afeta a forma do feixe, havendo continuidade e uniformida de morfológica no feixe que atravessa o MI. Neste estágio o MI já está maduro e não há mais divisão celular (Fig. 21, IV, Figs.17, 19) .

As pesquisas sobre a formação e desenvolvimento do plexo nodal revelaram importantes caracteristicas varie tais entre os cultivares NA 56-79 e CB 49-260.

KUMAZAWA (op. cit.) esclareceu a origem do ple xo nodal, a partir de um promeristema especial que se desen- 


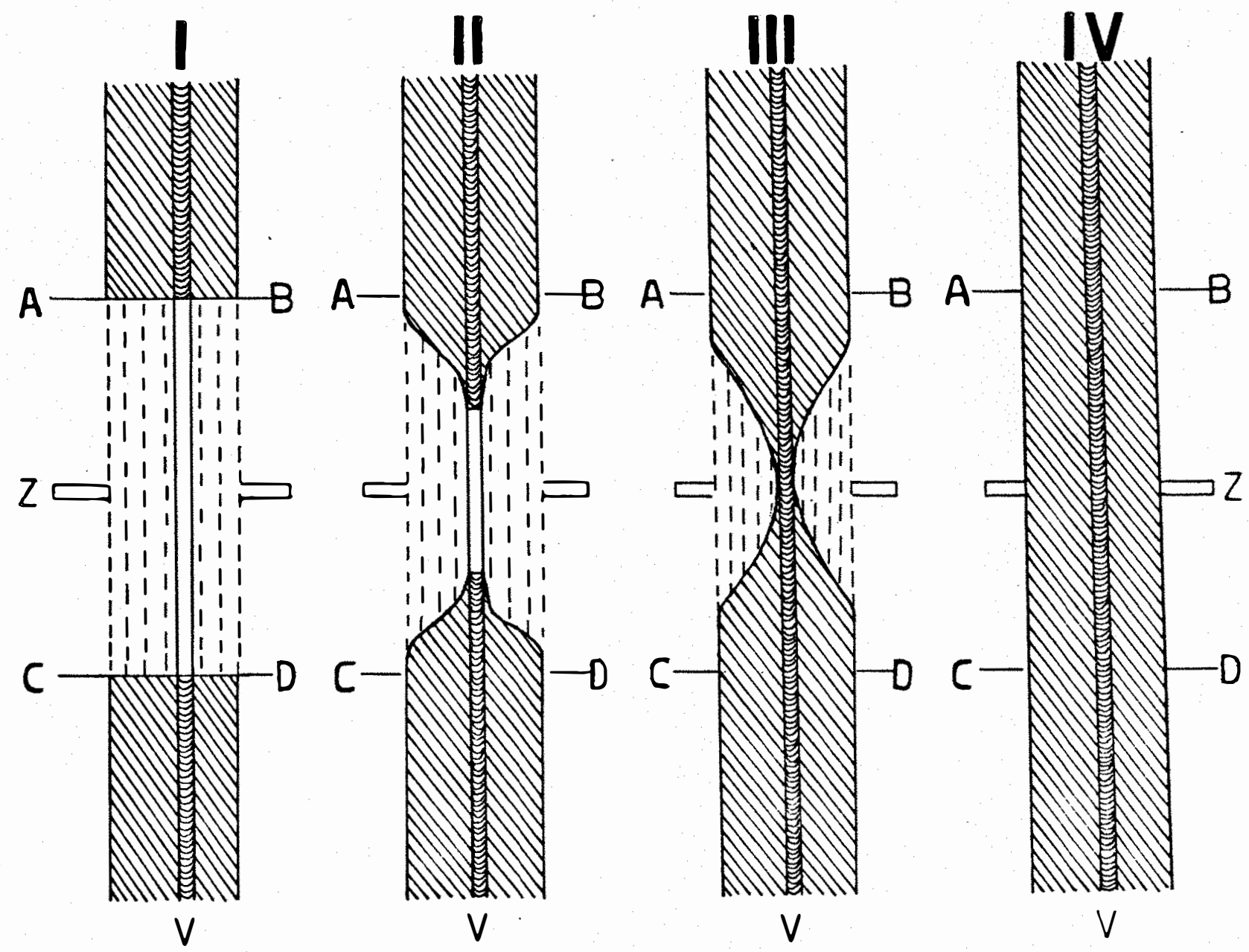

Figura 21. Estágios de amadurecimento dos feixes fibrovasculares na área do meristema intercalar: $\overline{\mathrm{ABCD}}-\bar{a}$ rea do meristema intercalar; $\mathrm{z}$ - zona de di visão celular; v - vasos; v-anelado - vasos lignificados; v-vazio - vasos celulósicos; áreas achuradas - esclerênquima; áreas de linhas segmentadas - colênquima. As áreas acima do plano $A B$ estão no internódio superior e as que estão abaixo dopla no CD estão na região superior do nó (Original). 
volve plagiotropicamente por entre os feixes axótropos, na sua fase protoxilemática.

No Cv. NA 56-79, no nó +1, verifica-se que o promeristema de Kumazawa se distribui por toda a extensão do PN, produzindo feixes plagiótropos. Os feixes axótropos, or $\underline{i}$ ginados do promeristema apical, amadurecem centrifugamente enquanto que os plagiotropos que vão formar $\circ \mathrm{PN}$, amadureœm si multaneamente, em toda a área do PN.

No cv. CB 49-260, aparentemente, não se forma um promeristema de Kumazawa generalizado em toda a área do PN, mas forma-se um promeristema individual para cada feixe plagiótropo que se desenvolve como ramificação dos axótropos, à medida em que estes vão amadurecendo.

Assim, no cV. NA 56-79, O PN se forma simultaneamente em toda a área, já no nó +1. E, no nó +2, ele já está amadurecido. No CV. CB 49-260, no entanto, O PN vai se formando gradualmente, acompanhando o desenvolvimento dos fe xes axótropos e, somente no nó +5 ele atinge a maturidade, juntamente com os feixes do SC. Essa mesma tendência se nota, para cada cultivar, no desenvolvimento dos traços gemares.

5.2. Discussão dos resultados

Estas pesquisas revelaram que existem algumas diferenças na arquitetura definitiva dos sistemas fibrovascu- 
lares dos dois cultivares estudados - NA 56-79, precoce, e CB 49-260, tardio - especialmente diferenças ontogênicas mui to importantes, em relação ao PN e MI desses dois cultivares. Essas diferenças se referem ao gradiente e ao sentido do amadurecimento dos feixes fibrovasculares. no colmo.

Assim, no cv. CB 49-260, O amadurecimento dos feixes no MI, é tipicamente centrípeto, ao passo que, no cv. NA 56-79 êle é tipicamente centrífugo (ver item 4.3. e subItens) e, portanto, semelhante ao do milho, também centrífugo

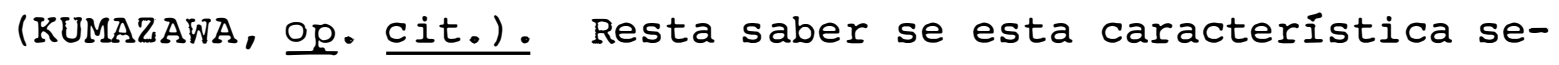
ria típica de cultivares tardios e precoces, respectivamente.

o amadurecimento centrífugo, ou centrípeto dos sistemas fibrovasculares tem importante influência na precocidade da germinação das gemas.

A capacidade de germinação de uma gema depende da presença de traços gemares maduros. No amadurecimento cen tripeto, amadurecem primeiro os feixes centrais mais próximos da periferia e, portanto, da gema, e os traços gemares de rivados desses feixes. Então, ainda no início do amadurecimen to do $\mathrm{PN}, \mathrm{já}$ existem traços gemares maduros, que permitem a germinação da gema.

Assim, no CV. CB 49-260 (item 4.4.) a gema do nó +2 é a mais nova germinante, embora se complete o PN somen te no nó +5 (item 4.3.).

No amadurecimento centrífugo, os feixes axótro pos vão amadurecendo do centro para a periferia, assim como 
os traços gemares que são seus ramos plagiótropos. O experimento de germinação (item 4.4.) mostrou que à gema do nó +3 é a mais nova germinante no cv. NA 56-79, embora o PN aparentemente já esteja completo no nó +2 Figura 13).

Os catafilos dos cvs. NA 56-79 e CB 41-76 apre sentam notáveis diferenças arquiteturais e de densidade de feixes (item 4.1.3.), que podem servir como características de diferenciação taxonômica.

\subsection{Origem e trajeto dos feixes}

A origem dos sistemas fibrovasculares foi determinada no tolete e no rizoma dos cvs. NA 56-79 e CB 41-76. Dois caminhos foram sequicios: a) o de partir de um traço foliar e acompanhar o feixe respectivo em seu trajeto descemden te até a sua origem (ítens 4.2.4. e 4.2.5.); b) o de partir dos traços gemares do tolete acompanhando os feixes deles deriva dos no rizoma e no colmo (4.1.1. e 4.1.2.) até o traço foliar.

Como consequência desses estudos ficou esclare cido o seguinte:

1. 0 sp do rizoma e do colmo se origina no $S P$ do tolete;

2. O sc do rizoma e do colmo tem duas origens: a) em sua grande maioria, os feixes do sc originam-se do SP 
do tolete; os feixes do sc podem ter origem também no $\underline{\text { sp }}$ do rizoma ou do colmo; b) em menor proporção, os feixes do sc do colmo e do rizoma originam-se do $\underline{\mathrm{SC}}$ do tolete.

\subsection{Considerações metodológicas}

Este trabalho, bastante dificultoso, somente pôde ser realizado pela adoção do método deenvelhecimento prẹ coce da cana-de-açúcar (item 3.1.). Por esse método, foi pos sível obter-se plantas com internódios muito curtos, de modo que em um trecho de colmo de cerca de $35 \mathrm{~cm}$ puderam ser contados 17 internódios e 15 nós, no cv. NA 56-79, e 18 internó dios e 16 nós no $\mathrm{Cv}$. $\mathrm{CB}$ 41-76.

Por outro lado, foi observado um fato digno de nota: a celulolisação de metades de colmos crescidos em condições normais, leva cerca de 100 dias para se completar. Entretanto, nos colmos envelhecidos precocemente, a celulolisação se completa em cerca de 50 dias. A única explicação plausivel para esse fato é que o envelhecimento precoce produz gran de quantidade de esclerenquima por unidade de volume, em detrimento da quantidade de tecidos celulósicos, ao passo que,

nos colmos de crescimento normal, a quantidade de celulose é grande, em relação à quantidade de esclerenquima, por unidade de volume.

A celulolisação sempre se inicia na região dos MI de todos os intemódios, progredindo para cima e para baixo. 
A falta de uma metodologia adequada para estudar a arquitetura fibrovascular de colmos, rizomas, raízes e outros órgãos fibrosos, tem retardado a obtenção de conhecimen tos anatômicos importantíssimos sobre tais órgãos. Muitos autores tentaram interpretar arquiteturas fibrovasculares de nós de gramíneas com base em cortes seriados, absorção de corantes vitais etc., mas não conseguiram interpretações corretas (AREVALO, 1983).

o método microbiocelulolítico, aliado com o do envelhecimento precoce abre um campo enorme de pesquisas dentro do setor da anatomia vegetal, pois inúmeras interpretações deverão ser revistas. 
74.

\section{CONCLUSÕES}

Os objetivos deste trabalho foram o de elucidar completamente a arquitetura fibrovascular do caule (tolete, ri zoma e colmo) da cana-de-açúcar, e determinar a posição do nó em que o plexo nodal (PN) já é funcional, em um cultivar precoce (NA 56-79) e em um tardio (CB 49-260).

Esses objetivos foram plenamente atingidos, pe la aplicação dos métodos de envelhecimento precoce e microbiocelulolisação da cana-de-açúcar, tendo resultado nas seguintes conclusões.

\subsection{Organização da rede fibrovascular}

A rede fibrovascular da cana-de-açúcar é constituída de dois sistemas de feixes:

a) Sistema periférico (sp) - formado de cordões multifasciculados que, originando-se no sistema periféri co (SP) do tolete, penetram no rizoma e passam para o colmo, 
percorrendo-o, periféricamente, em toda a sua extensão (Figu $\operatorname{ras} 3,5,6,7,10,11$ etc.).

b) Sistema central (sc) - formado de feixes fibrovasculares isolados que, podendo se originar tanto no SP como no SC do tolete, penetram na região central do rizoma e passam para o colmo, percorrendo-o centralmente, em toda a sua extensão. Muitos feixes deste sc originam-se no sp do rizoma e do colmo (Figuras $3,5,6,7,10,11$, etc.).

Os dois sistemas, ao penetrarem em um nó, produzem ramificações de seus respectivos feixes. Essas ramificações são plagiótropas e constituem, em seu conjunto o plexo nodal. Nos internódios, os dois sistemas são paralelos e não se ramificam.

6.2. Ramificações dos cordões do sp

As ramificações dos cordões do sp são:

a) Traços gemares periféricos (tgp) ;

b) Traços foliares periféricos (tfp);

c) Traços radicais (tr).

6.3. Trajetória dos feixes de traços foliares centrais

Os feixes que originam traços foliares centrais percorrem, em seu curso descendente, vārios internódios, fun- 
dindo-se, nas imediações da mesma ortóstica, com o sp do rizoma ou do colmo. Em relação ao trajeto desses feixes, não há diferença entre os cultivares estudados (Figuras y e 9).

\subsection{Ramificações e conexões dos feixes centrais}

Os feixes de traços foliares, no seu trajeto através do colmo e do rizoma, ramificam-se em alguns nós e não se ramificam em outros. As principais ramificações, nos nós, são os traços gemares centrais ( $\mathrm{tg}$ ), os traços foliares terminais $\left(t f_{1}, t f_{2}, t f_{3}\right)$ e os traços foliares laterais (tI) (Fi guras $3,5,8$ e 9).

As conexões são entre feixes centrais (cc), e en tre feixes do sc e cordões do $\underline{s p}(\underline{p p})$.

\subsection{Diferenças varietais.}

As pesquisas revelaram as seguintes diferenças varietais, nos cvs. NA 56-79, CB 49-260 e CB 41-76:

a) No cv. NA 56-79, o desenvolvimento do PN é simultâneo, a partir do promeristema de $\mathrm{Ku}-$ mazawa e o amadurecimento dos feixes axótro pos é centrífugo, revelado na evolução do MI, como ocorre em Z. mays; 
b) No CV. $C B$ 49-260, o desenvolvimento do PN não é simultâneo, mas gradual, a partir de um promeristema individual para cadafeixe do PN, e acompanhando o desenvolvimento dos feixes axótropos, que é centrípeto, revelado pela evolução do MI;

c) A capacidade de germinação das gemas é independente do amadurecimento completo do PN, mas depende exclusivamente do amadurecimento de traços gemares. Assim, em CB 49-260, é o nó +2 que tem traços gemares amadurecidos, permitindo a germinação, ao passo que NA 56-79 somente apresenta traços gemares maduros no nó +3 ;

d) A arquitetura fibrovascular dos catafilos é típica para cada um dos cultivares estudados - NA 56-79 e CB 41-76 - constituindo caráter de identificação taxonômica.

6.6. Diferenças arquiteturais entre. Z. mays e Saccharum spp.

a) Tanto a cana-de-açúcar como o milho apresen tam os mesmos sistemas fibrovasculares-dois axótropos (periférico e central) e um plagiótropo (plexo nodal): 
b) Em cana-de-açũcar, os três sistemas são interconectados. Em milho, segundo KUMAZAWA (op. cit.), não há conexão entre o sistema periférico e o central, nem entre os sistemas axótropos e o plexo nodal, a não ser acidentalmente;

c) O gradiente de amadurecimento dos feixes axótropo e centrífugo em milho (KUMAZAWA, op. cit.; SHARMAN, op. cit.). Em cana-deaçūcar, ele é centrípeto no cv. CB 49-260 e centrífugo no cV. NA 56-79;

d) Em relação ao curso descendente dos feixes centrais, nota-se que, em milho, esses feixes passam por vários internódios e se fundem, do mesmo lado ou do lado oposto do tra ço foliar, com o sistema periférico. Em ca na-de-açúcar só foram encontrados feixes centrais que, após seu curso descendente, se fundem com o sistema periférico do mesmo la do do traço foliar;

e) Em relação à origem topográfica dos feixes axótropos, nota-se que, no milho (nascido de cariópse) ambos os sistemas originam-se do sistema periférico do mesooōtilo. En cana-de-açúcaresses feixes poderrse originar tanto no sistema periférico como no central do tolete. 


\section{IITERATURA CITADA}

AREVALO, R.A., 1983. Arquitetura da rede fibrovascular nodal do colmo da cana-de-açúcar (Saccharum spp.). Piracicaba. ESALQ/USP. 98p. (Dissertação de Mestrado).

ARTSCHWAGER, E., 1925. Anatomy of the vegetative organs of the sugar cane. Jour. Agric. Res., 30: 197-221.

DILLEWIJN, C. van, 1952. Botany of sugarcane. New York. Chronica Botanica Publications. $371 \mathrm{p}$.

KUMAZAWA, M., 1961. Studies on the vascular course in maize plant. Phytomorphology, 1l(1-2): 128-139.

LAUBENGAYER, R.A., 1949. The vascular anatomy of the eight-rowed ear and tassel of golden bantam sweet com. Amer. J. Bot., 36 : 236-244.

REEVES, R.G., 1946. Methods for studying the maize ear. Bot. Gaz.., 107: 425 .

REEVES, R.G., 1950. Morphology of ear and tassel of maize. Amer. J. Bot., 37: 697-704. 
SHARMAN, B.C., 1942. Development anatomy of the shoot of Zea mays I. Ann. Bot., 6: 245-282.

TANIMOTO, T., 1964. Microtome-slice projections for histological examination of sugarcane. Hawailan Planter Record 57: $119-132$. 